\title{
Canadian Journal of Neurological Sciences
}

\section{Le Journal Canadien des Sciences Neurologiques}

\author{
Volume 7
}

January to December, 1980 


\section{Author Index to Volume 7}

The full citation is listed under the name of the first author. Other authors are referred to the name of the first author. Abs = abstract.

\begin{abstract}
Abdollah H, Howse D C N, Giles A R, Riopelle $R$ J: An Unusual Case of Acute Inflammatory Polyneuropathy - The Role of Pregnancy, Rhesus Immune Globulin, and Plasmapheresis, 325 (Nov) Abs
\end{abstract}

Adams J E: See Newfield P

Aguayo Albert J: See Perkins C Suzanne

Ali-Khan Z: See Hwang Paul A

Allan T: See Pecknold J C

Allard P, Duhaime M, Raso J V, Thiry P S, Drouin G, Geoffroy G: Pathomechanics and Management of Scoliosis in Friedreich's Ataxia Patients, 383 (Nov)

Allen Jeffrey C, Helson Lawrence: Response of Recurrent Medulloblastoma to High Dose Cyclophosphamide, 331 (Nov) Abs

Ameli N O: Hemispherectomy for the Treatment of Epilepsy and Behavior Disturbance, 33 (Feb)

Amin I: See Upton A R M

Amin M M, Khalid R, Lehmann H E: MHPG and Depression, 227 (Aug) Abs

Andermann E, Eisen A, Kirkham T, Andermann F, Carpenter S, Karpati G, Barbeau A: An Autosomal Recessive Syndrome of Mental Retardation, Seizures in Infancy, and Progressive Multisystem Degeneration, 323 (Nov) Abs Sherwin A, Andermann F, Dansky L, Loughnan P, Gibbons J E: Dermatoglyphic Alterations are a Subtle Indicator of Anticonvulsant Effect on the Fetus, 325 (Nov) Abs - See Pasternac A - See Tolis G

Andermann F: See Andermann E See Hwang $P$ See Tolis G See Zifkin B

Andrews David F: See Tator Charles H See Thompson M W

Annable Lawrence: See Chouinard Guy

Appeltauer L: See Pecknold J C

Araki G: See Nagata K

Arfors K E: See DelMaestro R F

Arpin E J: See Hwang Paul A

Arsenault M: See Bouvier G

Atack E A: See Hylton D See O'Brien Beth

Atkinson Burr G, Shivers Richard R: An Immunochemical and Polyacrylamide-gel Fluorographic Analysis of the Protein Synthesized in Normal and Dystrophic Murine Skeletal Muscle, 121 (May) Abs - See Shivers Richard R

Atwood H L: See Silverman H

Aube M: See Hwang Paul A

Averback P: Immunohistochemical Study of

Foci of Recent Cell Death in Huntington's Disease, 87 (May)

Azari J, Brumbaugh P, Barbeau A, Huxtable R:
Taurine Decreases Lesion Severity in the Heart of Cardiomyopathic Hamsters, 435 (Nov)

Bachevalier Jocelyne: See Botez M I

Bag Jnanankur, Sells Bruce $\mathrm{H}$ : Regulation of Protein Synthesis in Embryonic Chicken Muscle by Proteins that Bind to Messenger Ribonucleic Acids, 125 (May) Abs

Bailey S: See Johnson D D

Baker G B, Coutts R T, LeGatt D F: A Novel Procedure for Isolation and Quantification of Para-Tyramine in Rat Brain, 235 (Aug) Abs - See Calverley D G - See Petrali E H

Baker J M, Handley S L, Waldron G, Dunn T L: Seasonal Variation in Occurrence of PostPartum "Blues", 238 (Aug) Abs - See Cottle M K W - See Locock R A

Ball M J: Features of Creutzfeldt-Jacob Disease in Brains of Patients with Familial Dementia of Alzheimer Type, 51 (Feb) Nuttal K: Quantitative Histotopography in Down's Syndrome: Comparisons with Normal Aging and Alzheimer's Dementia, 336 (Nov) Abs See Merskey H

Bamford Colin R, Smith Michael S, Sibley William A: Horner's Syndrome, An Unusual Manifestation of Multiple Sclerosis, 65 (Feb)

Banna M: See Schatz S W

Barber B H: Is the Abnormal Gene Product in Duchenne Muscular Dystrophy (DMD) Expressed as a Defect in the Cytoskeleton of Fibroblasts in Culture?, 115 (May) Abs

Barbeau A: Friedreich's Ataxia 1980. An Overview, 455 (Nov) Charbonneau M, Cloutier T: Leucocyte Glutamate Dehydrogenase in Various Forms of Ataxia, 332 (Nov) Abs

Charbonneau M, Cloutier T: Leukocyte Glutamate Dehydrogenase Activity in Various Hereditary Ataxias, 421 (Nov)

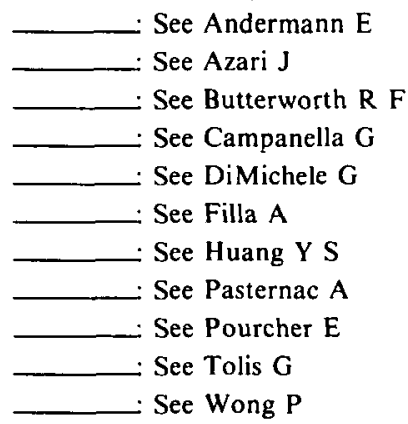

Barbeau H: See Richards C

Barnett $\mathbf{H} \mathbf{J}$ M: The Rationale and Progress of the Collaborative EC/IC Bypass Study, 327 (Nov) Abs
See Fox A

Barrows $\mathbf{H}$ : The Design and Evaluation of a Problem Based Learning Approach in Undergraduate Neurology, 327 (Nov) Abs

Barth R: See Elce John S

Bass B: See Paty D W

Bauman A: See Bruni J

Beaudry R: See Lapointe L R

Becker L: See MacGregor D L

Becker W J, Seland T P, West G R, Hoyte K M: Visual Evoked and Auditory Brainstem Responses in Patients with Spinal Cord Demyelination, 324 (Nov) Abs Sutherland L R, Muller $P$ J: Cerebral Edema in Acetaminophen Overdose, 320 (Nov) Abs

Bedard, P: See Bouchard J P

Bedwell Stephen F: D'Anville's Doom. A Neurological Vignette from Historic Halifax, I (Feb)

Befus A Dean, Johnston Neil, Bienenstock John, Butler Jane, Cosmos Ethel: Thymic Mast Cells in the Genesis of Avian Muscular Dystrophy, 124 (May) Abs

Beique R: See Bouvier G

Belmonte M: See Keene D L

Benoit B G, Preston D N, DaSilva V: An Evaluation of Silastic Sheathing in Neurolysis of the Ulnar Nerve, 324 (Nov) Abs - See Bornstein R

Beresford Bonnie: Embryonic Development of Avian Brachial Muscles, 117 (May) Abs

Bergeron C: See Rewcastle N B

Bernier J P, Lemieux B: Facio Scapulo Humeral Dystrophy: The Infantile Variety (IFSH), 333 (Nov) Abs

Bertagnolio B, Uziel G, Bottachi E, Crenna G D'Angelo A, DiDonato S: Friedreich's Ataxia in Northern Italy. II. Biochemical Studies in Cultured Cells, 409 (Nov)

Bertrand G: See Villemure J G

Beulche F: See D'Angelo A

Bhargava A K: See Hudecki M S

Bickford R G: See Wong P K H

Bienenstock John: See Befus A Dean

Biggs D F, Peterson M A: Airway Constriction Following Stimulation of the Glossopharyngeal Nerves, 232 (Aug) Abs

Bigner D: See Steinbok P

Bigner R U: See Steinbok $P$

Bilbao J M: See Horsey W J

Binik Y M: See Young $S \mathrm{~N}$

Blouin A: See Trites R L

Blume W T: See Gamache F W See Girvin J P See Jones D C See Merskey H See Pillay N See Young G B 
Blundell John E: See Leblanc Richard See Nudleman $K$

Boegman R J: See Riopelle R J

Boeri R: See D'Angelo A

Bolton C F: Peripheral Neuropathies Associated with Chronic Renal Failure, 89 (May) Carter K M, Lindsay R M, Clark W $\mathrm{F}$, Linton A L: Middle Molecule Clearance in Uremia: Effects on Peripheral Nerve Conduction and Platelet Function, 322 (Nov) Abs See MacDonald David $\mathbf{R}$ - See Young G B

Bornstein R, Benoit B G, Trites R L: Neuropsychological Assessment of the Effects of Carotid Endarterectomy, 329 (Nov) Abs

Menon Devidas, York Ernest,

Sproule Brian, Zak Cynthia: Effects of

Venesection on Cerebral Function in Chronic

Lung Disease, 293 (Nov)

Botez M I, Bachevalier Jocelyn, Tunnicliff G: Dietary Folic Acid and the Activity of Brain Cholinergic and y-Aminobutyric Acid (GABA) Enzymes, 133 (May)

Bottachi E: See Bertagnolio B

Bouchard J P, Bedard P, Bouchard R: Study of a Family with Progressive Ataxia, Tremor and Severe Distal Amyotrophy, 345 (Nov) - See Richards C

Bouchard R: See Bouchard J P See Richards C

Boule Marie: See Brakier-Gingras Lea

Boulton Alan A: Trace Amines and Mental Disorders, 261 (Aug)

: See Davis B A - See Durden D A

Bourassa M: See Galeano C

Bouvier G, St. Hilaire J M, Maltais R, Leduc A, Beique R, Desrochers P, Picard R, Arsenault $M$ : Surgical and Electronic Instrumentation for the Functional Exploration of Epilepsy, 325 (Nov) Abs

Boyd Michael, Watts A R, Bowering $M$ W: Monitoring Requirements During Carotid Endarterectomy, 321 (Nov) Abs

Bowering M W: See Boyd Michael

Brakier-Gingras Lea, Boule Marie, Vanasse Michel: Changes in the Protein Synthesis Activity of Polysomes from Fibroblasts of Patients and Carriers with Duchenne Muscular Dystrophy, 115 (May) Abs

Brants T: See Trites R L

Bray G M: See Duncan I D

$$
\text { - See Perkins C Suzanne }
$$

Bressler Bernard H., Charbonneau Johanne D: Isometric Contractile Properties of Dystrophic Mouse Muscle of the $\mathrm{C} 57 \mathrm{BL} / 6 \mathrm{~J}$ dy $2 \mathrm{~J} / \mathrm{dy}$ 2J Strain, 121 (May) Abs See Slonecker C.E.

Bril Vera, Humphrey John G: Proximal Nerve Conduction in Idiopathic Chronic Relapsing Polyneuropathy, 322 (Nov) Abs

Britt B: See Gordon A S

Broughton R, Ghanem Q, Hishikawa $Y$, Sugita Y, Nevsimalova S, Roth B: Socio-economic and Related Life-Effects in 180 Patients with Narcolepsy-Cataplexy From Populations in
North America, Asia and Eruope Compared to Matched Controls, 333 (Nov) Abs

$$
\text { Mamelak Mortimer: Effects of }
$$

Nocturnal Gamma-Hydroxybutyrate on

Sleep/Waking Patterns in Narcolepsy-

Cataplexy, 23 (Feb)

Brown G M: See Cleghorn J M

$$
\text { See Grof Eva }
$$

Brown $S$ M: See Warren $K G$

Brown William F: End-Plate Activity in Man, 333 (Nov) Abs

Yates S K: Discreet Localization of

Human Entrapment Neuropathies, 336 (Nov) Abs

Brownell A K W, Szabo M: The Influence of the Histochemical Profile of Muscle on the In Vitro Caffeine Contracture Test, 327 (Nov) Abs

Bruce Derek A, Schut Luis: Royal College Lecture: "Malignant" Brain Edema in Children, 335 (Nov) Abs

Brumbaugh P: See Azari J

Bruni J, Wilder B J, Bauman A: Prospective Study of Efficacy and Toxicity of Carbamazepine and Phenytoin as Primary Antiepileptic Drugs, 330 (Nov) Abs

Bullaro Joseph C: The Quantitation of Free and tRNA Bound Amino Acids Obtained From Single Monolayer Cultures of Skeletal Muscle, 118 (May) Abs

Burrow G: See Rewcastle N B

Butler Jane: See Befus A Dean

Butler J, Cosmos E: The Avian Latissimus Dorsi: II. Role of Neurons to Establish Embryonic Enzymic Patterns, 117 (May) Abs

Butterworth $\mathbf{R} F$, Landreville $F$, Hamel $E$, Merkel A, Giguere F, Barbeau A: Effect of Asparagine, Glutamine and Insulin on Cerebral Amino Acid Neurotransmitters, 447 (Nov) See DiMichele G See Filla A

Bylsma F W: See Pivik R T

Calverley D G, Baker G B, McKim H R, Dewhurst W G: A Gas Chromatograph Technique Using Electron Capture Detection for Simultaneous Estimation of Tryptamine and 5-Hydroxytryptamine in Biological Tissue, 237 (Aug) Abs See McKim H R

Cameron D A: See Riopelle R J

Camfield C: See Camfield P R

Camfield $\mathbf{P} \mathbf{R}$, Camfield $\mathrm{C}$ : Hydrocephalus Following Birth Weight Less Than $1500 \mathrm{~g}, 331$ (Nov) Abs

Tibbles J A R: Life Threatening Complications From Traditional Anticonvulsant Drugs, 325 (Nov) Abs

Campanella G, Filla A, DeFalco F, Mansi D, Durivage A, Barbeau A: Friedreich's Ataxia in the South of Italy - A Clinical and Biochemical Survey of 23 Patients, 351 (Nov)

Cardosa E R, Peterson E W: Blood-Brain Barrier (BBB) Dysfunction Following Experimental Subarachnoid Hemorrhage (SAH), 335 (Nov) Abs

Carlen P L: See Lee M A
Carlstedt T: See Perkins C S

Carpenter S: See Andermann E - See Karpati George

Carrouthers R: See Meguro K

Carter Susan Bonham: See Sandler M

Carter K M: See Bolton C F

Cates G A: See Holland Paul C

Cermak T: See Upton A R M

Chang L: See Stewart P A

Chang L S: See Percy M E - See Thompson M W

Chang Patricia L, Davidson Ronald G: A Test of Allelism in Clinical Variants of Inherited Diseases, 115 (May) Abs)

Charbonneau D: See Bressler Bernard H

Charbonneau M: See Barbeau A

Charlton M P: See Silverman H

Cheung S: See Warsh J J

Chew D L, Curry R: Carotid Doppler Imaging in a Community Hospital, 321 (Nov) Abs

Chin-See M W: See Nicholls D M

Chong G: See Hwang Paul A

Chretien M: See Galeano C

Chouinard Guy, Ross-Chouinard Andree, Annable Lawrence, Jones Barry D: Extrapyramidal Symptom Rating Scale, 233 (Aug) Abs

Clark W F: See Bolton C F

Clarke J T R: See Giffin F D

Cleghorn J M, MacCrimmon D J, Brown G M: Serum Prolactin and Growth Hormone Levels in Chronic Neuroleptic Responsive and Neuroleptic Nonresponsive Male Schizophrenics, 232 (Aug) Abs

Cloutier T: See Barbeau A

Cochrane D, Myles T: Guidelines for Management of Intra-Uterine Hydrocephalus, 332 (Nov) Abs

Colby-Germinario Susan, Martial Eleanora, Livett Bruce G: Investigations of Possible Immunocyte Involvement in the Murine Muscular Dystrophies, 124 (May) Abs

Cook A: See Little J R

Cook S A: See Little J R

Cooper I S: See Upton A R M

Cooper J K, Midha K K, Hubbard J W: Radioimmunoassay for Fluphenazine in Human Plasma, 235 (Aug) Abs See Hubbard J W See Midha K K

Cooper P W: See Vilaghy M I Cosmos Ethel: See Befus A Dean - See Butler J See Mazliah J

Cote M: See Lamarche J B

Cottle $\mathrm{M}$ K W, VanPetten G R, Johnson B, $\mathrm{Ng}$ P, Baker J M: Kinetics of Maternal-Fetal Alcohol Exchange, 236 (Aug) Abs

Coupland S G: See Kirkham T H

Cousin H K: See Paty D W

Coutts R T, Liu S F, Hargesheimer E E, Pasutto $F M$ : Studies on the Isolation and Quantification of Hydroxylated Amines in Aqueous Solution, 236 (Aug) Abs See Baker G B 
Creasy R C: See Nicholls D M

Crenna G: See Bertagnolio B

Cross David: See Peterson Alan C

Curry Bernadette, Sima Anders A F: Dyplastic Vertebral Artery with Paradoxical Infarction, 313 (Nov)

Curry R: See Chew D L

Dallaire L: See Melançon S B

D'Alton J, Preston D N: $256 \mathrm{~Hz}$ Vibration in the Carpal Tunnel Syndrome, 324 (Nov) Abs

D’Angelo A, DiDonato S, Negri G, Beulche F, Uziel G, Boeri R: Friedreich's Ataxia in Northern Italy. I. Clinical, Neurophysiological and In Vivo Biochemical Studies, 359 (Nov) - See Bertagnolio B

Dansky L: See Andermann E

DaSilva V: See Benoit B G - See Ventureyra E C G

Davidson Ronald G: See Chang Patricia L

Davignon J: See Huang Y S

Davis Alan E, Lee Robert G: EMG Biofeedback in Patients with Motor Disorders: An Aid for Coordinating Activity in Antagonistic Muscle Groups, 199 (Aug)

Davis B A, Boulton A A: Urinary Excretion of Labelled Metabolites Following Ingestion of Deuterated Phenylethylamine in a Human Male, 23l (Aug) Abs

DeBrun G: See Fox A

Deck J H N: See Schutz Hart

DeFalco F: See Campanella G

Deikel S M: See Young S N

Del Maestro R F, Arfors K E: The Cerebral Dynamics of Albumin and Water Flux After Intracarotid Injection of Hyperosmolar Solutions, 334 (Nov) Abs

DeMichele G, Jolicoeur F B, Rondeau D B, Butterworth R F, Barbeau A: Effects of Glutamate and Aspartate on Ataxic Gait Induced by 3-acetyl pyridine in Rats, 451 (Nov)

d'Entremont D M: See Giffin F D

Desrochers P: See Bouvier G

Dewhurst W G: See Calverley D G See McKim H R

Dibkin Barbara: See Ridgley B A

DiDonato S: See D'Angelo A : See Bertagnolio B

Dinsdale H B: See Nag S

Dobbs Allen: See Menon Devidas

Donaldson J, LaBella F S, Gesser H: A Proposal for the Pathogenesis of Parkinson's Disease Based on Dopamine Neurotoxicity, 234 (Aug) Abs

Douglass A: See Hopkinson $G$

Drake C G: See Ferguson G G

Draper $\mathbf{P}$, Shapcott $D$, Langlois $M$, Lemieux B: Glycosylated Hemoglobins in Friedreich's Ataxia, 405 (Nov)

Drouin G: See Allard $P$

Dryden W F, Thomson C M: Electrophysiological Development in Dystrophic Muscle Grown in Culture, 119 (May) Abs
Duhaime M: See Allard $P$

Duncan I D, Griffiths I R, Bray G M: A New Inherited Canine Hypomyelinating Disorder Associated with Congenital Tremor, 328 (Nov) Abs

Dunn H G: Peripheral Neuropathies in Childhood, 325 (Nov) Abs

Dunn T L: See Baker J M

Durden D A, Boulton A A: Regional Distributions of $\mathrm{m}$ - and $\mathrm{p}$-Hydroxyphenylacetic Acids in Rat Brain, 234 (Aug) Abs

Durivage A: See Campanella G

Dyck Lillian E: Selective Release of Tritiated p-Tyramine (pTA) From Rat Striatal Slices, 230 (Aug) Abs

Ebers G C, Paty D W: CSF Electrophoresis in One Thousand Patients, 275 (Nov) Paty D W: Optic Neuritis (O.N.) in

Familial M S, 332 (Nov) Abs See Feasby Thomas E

Edmonds Virginia E: See Tator Charles H

Eisen Andrew, Elleker George: Evaluation of Radiculopathies and Plexopathies Using Segmental Sensory Stimulation, 322 (Nov) Abs - See Andermann E - See Karpati G

Elbrink J: See Hunter E G

Elce John S, Barth R, Franchi L: $\mathrm{CA}^{++}$ Dependent Neutral Proteinase in Hamster Lung, Heart, and Skeletal Muscle, I14 (May) Abs

Elgie R G: See Hugenholtz H

Elleker George: See Eisen Andrew

Enna S J: GABA and Neuropsychiatric Disorders, 257 (Aug)

Enns L, McCoy E E: Relationship of Serotonin Uptake to $\mathrm{NA}^{+}$and $\mathrm{K}^{+}$Content in Down's Syndrome and Normal Platelets, 238 (Aug) Abs

Evelyn R: See Purves Sherrill J

Fabenyi K: See Murphy E G

Fairholm D: International Neurosurgical Education - A Personal Perspective, 328 (Nov) Abs

Fariello R: See Murphy E G

Farrar J K: See Meguro K

Farrara J K: See Gamache F W

Farrell K: Clinical Seizure Forms in Temporal Lobe Epilepsy, 325 (Nov) Abs

Feasby Thomas E, Ebers George C, Paty Donald W, Fox Allan J: Spinal Cord Swelling in Multiple Sclerosis, 324 (Nov) Abs See Hahn A F

Ferguson G G, Drake C G: Carotid-Ophthalmic Aneurysms: 19 Cases Presenting with Compression of the Visual Apparatus Alone, 331 (Nov) Abs

\section{See Gamache F W}

- See Meguro K

Fibiger H C: Organization of GABA-Containing Neurons in Some Extrapyramidal Nuclei, 251 (Aug)

Filla A, Butterworth R F, Barbeau A: Active
Pyruvate Dehydrogenase in Platelets from Friedreich's Ataxia Patients, 417 (Nov) - See Campanella G

Finlayson D M: See Wortzman D J

Fisher $\mathbf{C} \mathbf{M}$ : Late-Life Migraine Accompaniments As A Cause of Unexplained Transient Ischemic Attacks, 9 (Feb)

Fleming J F R: See Schutz Hart

Fontaine G: See Melançon S B

Ford R M: See Holmberg R D

Fournier S A: See Hubbard J W

Fox A, Vinuela F, Barnett H J M, DeBrun G: Delayed Metrizamine C $\mathrm{T}$ in Syringomyelia, 328 (Nov) Abs

Fox Allan J: See Feasby Thomas E - See Merskey H

Fox Hannah: See Merskey $\mathbf{H}$

Fraenkel D: See Vickers J D

Frair Pat: See Peterson Alan C

Frair $\mathbf{P} \mathbf{M}$, Peterson A C: Gene Product Distribution in Mosaic Skeletal Muscle Fibres, 123 (May) Abs

Franchi L: See Elce John S

Freedman M H: See Percy M E

Fulton Dorcas $S$, Levin Victor A, Wilson Charles B: Chemotherapy of Pediatric Brainstem Tumors, 319 (Nov) Abs

Gabriel Youssef H: See Quartey Gilbert R C Gaginer J P: See Sourkes T L

Gaito John: The Effect of Variable Duration One Hertz Interference on Kindling, 59 (Feb) - Gradient of Interference by Various Frequencies on $60 \mathrm{~Hz}$ Kindling Behavior, 223 (Aug)

Galeano $C$, Bourassa $M$, Chretien $M$, Lis $M$ : Action of Chronic High Level of Endogenous Neuropeptides in Rats, 231 (Aug) Abs

Galloway Janice: See Purves Sherrill J

Gamache $\mathbf{F}$ W, Ferguson G G, Farrara J K, Blume $W$ T: Monitoring During Carotid Endarterectomy: Further Evidence that an Internal Shunt is Not Necessary, 326 (Nov) Abs

Gauthier S, Young S N: Serotonin Metabolism in Epileptic Patients, 326 (Nov) Abs - See Sourkes T L

Gentili Fred, Hudson Alan R, Hunter David: Clinical and Experimental Aspects of Injection Injuries of Peripheral Nerves, 143 (May) Hudson A R, Hunter D: The Role of the Blood/Nerve Barrier (BNB) in Normal and Injured Peripheral Nerve, 335 (Nov) Abs - See Hudson A R

Geoffroy G: See Allard P - See Melançon S B

Gershater R: See Wortzman D J

Gesser H: See Donaldson J

Ghanem Q: See Broughton R

Giard Normand: See Hausser Chantal $O$

Gibbons J E: See Andermann E

Gibson C J: See Young S N

Giffin F D, Clarke $J$ T R, d'Entremont D M: Effect of Dietary Phenylalanine Restriction on 
Visual Attention Span in Mentally Retarded Subjects with Phenylketonuria, 127 (May)

Giguere F: See Butterworth R F

Gilbert J J: See Hahn A F

Giles A R: See Abdollah H

Girvin J P, Blume W T: Cerebral Tumours in Childhood Presenting as Chronic Focal Epilepsy, 331 (Nov) Abs

$$
\text { - See McLachlan R S }
$$

Glover Vivette: See Sandler $M$

Godolphin W: See Purves Sherrill J

Godse D D: See Warsh J J

Gordon A S, Britt B: Post-operative Symptoms in Unrecognized Malignant Hyperthermia (M.H.) Reactions, 327 (Nov) Abs

Goswami T, Parvin R, Pande S V: A Method for the Rapid Isolation of Mitochondria from Skeletal and Cardiac Muscles Suitable for Small Tissue Samples, 120 (May) Abs

Greenblatt David J, Shader Richard I: Pharmokinetic Aspects of Anxiolytic Drug Therapy, 269 (Aug)

Griffiths I R: See Duncan I D

Grignon B: See Melançon S B

Grimes J D, Hassan M N, Preston D N: Extrapyramidal Complications of Metoclopramide Therapy, 331 (Nov) Abs

Grof Eva, Grof Paul, Brown Gregory M, Saxena Bishan, Henry Ruth: Neuroendocrine Investigation of Healthy Volunteers on Nortriptyline and Lithium, 229 (Aug) Abs

Grof Paul: See Grof Eva

Guberman A: Clinical Value of the Corneomandibular Reflex, 327 (Nov) Abs

Guzman D A, Montpetit V: Intracranial Venous Thrombosis Occurring in Early Pregnancy, 321 (Nov) Abs

Guitton D: See Kirkham T H

Guzman D A: See Guberman A

Hachinski V C: See Kolin A See Vilaghy M I

Hahn A F, Feasby T E, Gilbert J J: Passive Transfer of Demyelinating Activity in Experimental Allergic Neuritis and Guillain-Barre Polyneuropathy, 116 (May) Abs

Gilbert J J, Hinton G: Hereditary

Demyelinating Infantile Neuropathy with

Unusual Clinical and Pathological Findings,

323 (Nov) Abs

Hamel E: See Butterworth R F

Handley S L: See Baker J M

Hardy J: See Mohr G

See Ouaknine G E

Hargesheimer E E: See Coutts R T

Harvey C: See Pasternac A

$$
\text { See Tolis G }
$$

Harwood-Nash Derek C: See Hoffman Harold J

Hassan M N: See Grimes J D See Hylton D

Hausser Chantal 0, Robert Francoise, Giard

Normand: Balint's Syndrome, 157 (May)

Havlicek V: See West M

Heffernan L P M: See Noseworthy J H
Heffner R R: See Hudecki M S

Helson Lawrence: See Allen Jeffrey $C$

Henry Ruth: See Grof Eva

Hersch E L: See Merskey H

Heyman A: See Rothman S J

Hinton G: See Hahn A F

Hiob L E: See Petrali E G

Hishikawa Y: See Broughton R

Hoekman Theodore B: Therapeutic Trial of Oral Phenytoin in Dystrophic Chickens; Effects Upon Contractile and Electric Properties of Muscle, 120 (May) Abs

Hoffman Harold J, Harwood-Nash Derek C, Morley T P. Rewcastle N Barry: University of Toronto Neurosurgical Rounds No. 1. Massive Osteolysis in Association with Multiple Cerebrospinal Fluid Fistulae, 39 (Feb) See Horsey W J

Holgate R: See Rewcastle N B

Holland Paul C, Cates G A: Biosynthesis of Plasma Membrane Proteins in Normal and Dystrophic Muscle, 118 (May) Abs

Hollenberg R: See Nudleman $K$

Holmberg R D, Richardson P M, Ford R M, Stratford J G: Intracranial Pressure Monitoring in Head Injury: A Practical Experience, 319 (Nov) Abs

Holness R O, Huestis W S, Langille R A, Howes W J: Internal Fixation of Cervical Spine Dislocations with an Interlaminer Clamp, 329 (Nov) Abs See Wheelock W Brian

Hopkinson G, Douglass A: Kynurenine Excretion in Depressed States, 238 (Aug) Abs

Horowitz S, Rosenblatt B, O'Gorman G: Lissencephaly: Three Cases Diagnosed by C T Scan, 323 (Nov) Abs

Horrobin D F: Prallels Between Zinc Deficiency, Essential Fatty Acid Deficiency and Myotonic Dystrophy, 125 (May) Abs

Horsey W J, Bilbao J M, Nethercott J, Myers R, Hoffman H H: University of Toronto Neurosurgical Rounds No. 2. Oculodermal Melanosis (Naevus of Ota) Complicated by Multiple Intracranial Tumors, 101 (May)

Hosobuchi Y: See Newfield P

Howes $W$ J: See Holness R O

Howse D C N: See Abdollah $\mathrm{H}$

Hoyte K M: See Becker W J

Hrdina P D, LaPierre Y D: Clinical Response Plasma Levels and Pharmacokinetics of Desipramine in Depressed Patients, 228 (Aug) Abs

Huang Y S, Marcel Y L, Vezina C, Barbeau A, Davignon J: Lecithin: Cholesterol Acyltransferase Activity and Fatty Acid Composition of Erythrocyte Phospholipids in Friedreich's Ataxia, 429 (Nov) See Maas J W

Hubbard J W, Cooper J K, Fournier S A, Midha K K: Radioimmunoassay for Trifluoperazine in Human Plasma, 237 (Aug) Abs See Cooper J K See Midha K K

Hudecki M S, Pollina C M, Bhargava A K, Hudecki $R$ S, Heffner $R$ R: Genetically
Dystrophic Chicken Employed as Model for Drug Therapy Screening, 124 (May) Abs

Hudecki R S: See Hudecki M S

Hudson A R, Gentili F, Hunter D: The Role of Internal Neurolysis in Peripheral Nerve Surgery, 335 (Nov) Abs - See Gentili Fred

Huestis W S: See Holness R O

Hugenholtz H, Payne F J, Elgie R G: Early vs Delayed Repair of Ruptured Intracranial Aneurysm, 330 (Nov) Abs

Humphrey J G, Shumak K H, McLean D R: Plasma Exchange and Myasthenia Gravis, 334 (Nov) Abs - See Bril Vera

Humphreys P: See Nudleman K

Humphreys R P: See Schutz Hart

Hunter Daniel: See Gentili Fred See Hudson A R

Hunter E G, Elbrink J: The Effect of 2, 4-Dinitrophenol on the Electrical Activity of Normal and Dystrophic Diaphragm, 114 (May) Abs

Hurwitz B: See Rothman S J

Huterer S: See Wherrett J R

Huxtable R: See Azari J

Hwang Paul A, Ali-Khan Z, Arpin E J, Aube M, Chong G: Cerebral Cysticercosis in Canada: A Report on Three Cases from Montreal, 319 (Nov) Abs

Watters G, Metrakos K, Moroz B, Andermann F, Rosenblatt B: Neurologica Involvement in Children with Morphea (Localized Scleroderma), 331 (Nov) Abs

Hyde M L: See Yufe R S

Hylton D, Hassan M N, Lach B, Atack E A: Primary CNS Lymphomas: Clinical and Pathological Aspects, 333 (Nov) Abs

Jackson R: See O'Brien Beth

Jacob M: See Lee M A

Jacobs Hans $\mathbf{K}$, Weselake Randall $\mathrm{J}$ : Use of Antibodies in the Detection of Mitochondrial Creatine Kinases, 116 (May) Abs

Jamieson J C: See Parfett C L J

Janeczko R A: Myofibril Isolation for Protein Turnover Studies in Cultured Skeletal Muscle, 119 (May) Abs

Janjua $\mathbf{N}$ Aslam, Metrakos J D, Van Gelder N $\mathrm{M}$, Metrakos $\mathrm{K}$ : Plasma Amino Acids in Epilepsy, 328 (Nov) Abs

Jarvis S: See Murphy E G

Jasch L G: See Slonecker C E

Jasch Laura G: The Distribution of Proteins in the Slow-Twitch Soleus and Fast-Twitch Extensor Digitorum Longus Muscles of Normal and Dystrophic Mice, 121 (May) Abs

Jasmin G, Proschek L: Prevention of the Hamster Hereditary Cardiomyopathy by Verapamil, a Calcium Antagonist, 114 (May) Abs

Johnson B: See Cottle M K W

Johnson D D, Bailey S, Wenger B: Neural Extracts Do Not Influence Acetylcholinesterase Activity in Muscle Cultured from Dystrophic Chick Embryos, 118 (May) Abs 
Johnston B: See Seshia S S

Johnston Neil: See Befus A Dean

Jolicoeur F B: See DeMichele G

Jones A M: See Pivik R T

Jones Barry D: See Chouinard Guy

Jones D C, Blume W T: Aberrant Wave Forms

to Patterns Reversal Stimulation: Clinical,

Significance and Electrographic "Solutions", 326 (Nov) Abs

Jones R S G: Change in Responsiveness of Rat Cortical Neurones to Acetylcholine Following Chronic Administration of Atropine, Imipramine and Viloxazine, 23l (Aug) Abs

Juorio A V: Molindone on Mouse Striatal Tyramine, 229 (Aug) Abs

\section{Kaibara M: See McLachlan R S}

Kaplan Ronald, Tsaros Linda: Neurobehavioral Dysfunction in Multiple Sclerosis: A Major Cause of Adaptational Breakdown?, 323 (Nov) Abs

Karpati G, Carpenter S, Eisen A, Pena S: An Unusual Form of Centronuclear Myopathy with Copious Lipofuscin Accumulation in the Center of Muscle Fibers, 332 (Nov) Abs Carpenter Stirling, Lemieux Bernard: The Preclinical Stage of Duchenne Dystrophy, 115 (May) Abs

\section{See Andermann E}

Kasian G: See Seshia S S

Kawase T: See Nagata $K$

Keene D L, Metrakos K, Belmonte M, Watters $G$ V, Singer S: EEG Abnormalities and Convulsions in Juvenile Diabetes Mellitus A Follow Up Study, 333 (Nov) Abs

Keith William S: See Schutz. Hart

Kertesz Andrew, Sheppard Ann: The Anatomy of Jargon, 325 (Nov) Abs - See Rice G P A

Kettyls G D: See Warren K G

Khalid R: See Amin M M

Khan M: See Wherrett J R

Kirkham T H, Guitton D, Coupland S G: Giant Axonal Neuropathy: Visual and Oculomotor Deficits, 177 (Aug) See Andermann E

Koles Zoltan: See Menon Devidas

Kolin A, Norris J W, Hachinski V C: Myocardial Lesions in Acute Stroke: A Pathological Study, 321 (Nov) Abs

Koreska J: See Moseley C F

Kovacs K: See Rewcastle N B

Kral V A: See Merskey H

Krol R: See Pasternac A

Kwan Hon C: See Murphy John T

LaBella F S: See Donaldson J

Lach B: See HYlion D

Lamb S: See Newfield $P$

Langille R A: See Holness R O

LeBlanc F E: Stabilization of the Cervical Spine Using the Anterior Approach, 329 (Nov) Abs

Laguna Jose F: See Smith Michael S

Lamarche J B, Cote M, Lemieux B: The
Cardiomyopathy of Friedreich's Ataxia Morphological Observations in 3 cases, 389 (Nov)

Lamarche J: See Lapointe L R

Landreville F: See Butterworth R F

Langlois $M$ : See Draper $\mathbf{P}$

Lapczak L: See Thompson M W

Lapierre Y D: See Hrdina P D

See Midha K K - See Sussman P S

Lapointe L R, Lamarche J, Salloum A, Beaudry $R$ : Meningo-Ependymitis in Whipple's Disease, 163 (May)

Leblanc Richard, Blundell John E: Aneurysm of the Posterior Inferior Cerebellar Artery in a Child: Report of a Case with Survival, 301 (Nov)

Ledru E: See Melançon S B

Leduc A: See Bouvier G

Lee M A, Carlen P L, Jacob M, Livshits O: Parkinsonism Provoked by Alcoholism, 332 (Nov) Abs

Lee Robert G: See Davis Alan E

Legatt D F: See Baker G B

Lehmann H E: See Amin M M

Lemieux Bernard: See Karpati $G$

Lemieux B: See Bernier J P See Draper $P$ : See Lamarche J B

Levin Victor A: See Fulton Dorcas $S$

Lewis A J: See O'Brien Beth

Lewis Marcia E, Warren Kenneth G: Herpes Zoster Mandibularis, 153 (May) See Warren K G

Li P: See Warsh J J

Little J R, Cook A, Cook S A, MacIntyre W J: Plasma and Erythrocyte Flow in Acute Focal Cerebral Ischemia, 329 (Nov) Abs

Lindsay $\mathbf{R} \mathbf{M}$ : See Bolton C F

Linton A L: See Bolton C F

Lis $M$ : See Galeano C

Liv S F: See Coutts R T

Livett Bruce G: See Colby-Germinario Susan See Mizobe Fumio

Livshits O: See Lee M A

Lo Alex W: See Sharpe James A

Locock R A, Martin I L, Baker J M: High Pressure Liquid Chromatographic Determination of Chlorpromazine and its Metabolites in Plasma, 235 (Aug) Abs

Logan William J: Control of Muscle Cell Growth and Amino Acid Transport, 119 (May) Abs

Mok V, Swanson J M: Quantitative Analysis of Motor Function, 333 (Nov) Abs

Loughnan P: See Andermann E

Low M D: See Purves Sherrill J

MacCrimmon D J: See Cleghorn J M

MacDonald David R, Bolton Charles F: Anticoagulant Association Intracranial Hemorrhage, 320 (Nov) Abs

MacFadyen D J, Rozdilsky B. Stilwell G A: The
Treatment of Progressive Multifocal Leucoencephalopathy with Anti-DNA Virus Agents: A Case Report, 326 (Nov) Abs

MacGregor D L, Becker L: Moya-Moya Disease: A Clinical Pathological Correlation. 321 (Nov) Abs

MacIntyre W J: See Little J R

Mackay W A: See Murphy John T

Maas J W, Huang Y: Noradrenergic Function and Depression, Too Much or Too Little?, 267 (Aug)

Magnus O, Poortvliet D C J, Van Der Wulp C J $M$, Van Huffelen A C: Spectral Analysis of the Basic Activity for Clinical Application of the EEG Applied in Patients with Space Occupying Lesions, 333 (Nov) Abs

Mahaley M S: See Steinbok P

Maltais R: See Bouvier G

Mamelak Mortimer: See Broughton Roger

Mansi D: See Campanella G

Marcel Y L: See Huang Y S

Maroun F B: See Morrison D L See Russell Neville A

Martial Eleanora: See Colby-Germinario Susan - See Mizobe Fumio

Martin I L: See Locock R A

Martin W: See Purves Sherrill J

Matheson G Keith: See Tunnicliff Godfrey

Matthew E, Sherwin A L. Welner S A, Odusote K, Stratford J G: Seizures Following Intracranial Surgery: Incidence in the First PostOperative Week, 285 (Nov)

Mazliah J, Cosmos E: The Avian Latissimus Dorsi: I. Physiological and Structural Comparisons of the Phenotypically Affected PLD and the Spared ALD in Chickens with Hereditary Muscular Dystrophy, 117 (May) Abs

Meek D C, Tibbles J A R, Wort J: Spinal Subdural Empyema with Anaerobic Organisms, 323 (Nov) Abs

Meguro K, Ferguson G G, Farrar J K. Carrouthers R: Cerebral Blood Flow and Arterial Vasospasm in Patients with Subarachnoid Hemorrhage, 321 (Nov) Abs

Tator C H, Rowed D W: Favourable Results with the Syringo-Subarachnoid Shunt for the Treatment of Syringomyelia, 324 (Nov) Abs

Mehta A: See Tolis G

Melançon S B, Fontaine G, Geoffroy G. Vanasse M, Dallaire L: Correlation Between Serum Lipoamide Dehydrogenase Activity and Phosphatidyl Choline Therapy in Friedreich's Ataxia, 412 (Nov) - Grignon B. Ledru E, Geoffroy G. Potier M, Dallaire L, Vanasse M: The BetaAmino Acid Transport System in Friedreich's Ataxia, 441 (Nov)

Menon Devidas, Koles Zoltan, Dobbs Allen: The Relationship Between Cerebral Blood Flow and the EEG in Normals, 195 (Aug) See Bornstein Robert See Weir B

Merkel A: See Butterworth R F

Merskey H. Ball M J. Blume W T, Fox Allan J. 
Fox Hannah, Hersch E L, Kral V A, Palmer R B: Relationships Between Psychological Measurements and Cerebral Organic Changes in Alzheimer's Disease, 45 (Feb)

Metrakos J D: See Janjua N Aslam

Metrakos K: See Hwang $\mathbf{P}$ See Janjua N Aslam See Keene D L

Mezei C: Myelination in the Peripheral Nerve of Normal and Muscular Dystrophic Chicks During Development, 122 (May) Abs

Midha K K, LaPierre Y D, Cooper J K, Hubbard J W: Reduction of Plasma Levels of

Fluphenazine and Perphenazine by Rubber

Stoppers Used in Vacutainers, 235 (Aug) Abs : See Cooper J K See Hubbard J W

Mizobe Fumio, Martial Eleanora, Livett Bruce C: Measurements of Membrane Fluidity in Dystrophic Mice, 122 (May) Abs

Mizukami M: See Nagata $K$

Mizuno K: See Perkins C S

Mohr G, Ouaknine G E, Hardy J: The Value of Scanning Electron Microscopy in Experimental Microvascular Surgery, 329 (Nov) Abs

Mohr G: See Ouaknine G E

Mok V: See Logan W J

Monckton George, Pehowich Enid: Autonomic Neuropathy in the Streptozotocin Diabetic Rat, 135 (May)

Nihei T: The Changing Pattern of Protein Synthesis in the Dystrophic Chick Embryo, 118 (May) Abs

Montpetit V: See Guberman A

Morley T P: See Hoffman Harold J

Moroz B: See Hwang $P$

Morrison D L, Maroun F B: Intracranial Pressure Monitoring, 319 (Nov) Abs

Moseley C F, Koreska J: Orthopaedic Aspects of Duchenne Muscular Dystrophy (Medical Engineering and Computer Analysis), 116 (May) Abs

Muller P J: See Becker W J

Murphy E G, Vrancart C, Jarvis S, Fabenyi K, Fariello $R$, Yeung $C \mathrm{M}$ : $A$ Trial of Penicillamine in the Management of the Duchenne Type Dystrophy, 120 (May) Abs

Murphy John T, Kwan Hon C, MacKay W A, Wong Uiu C: Physiologic Basis for Focal Motor Seizures and the Jacksonian "March" Phenomena, 79 (May)

Myers R: See Horsey W J

Myles T: See Cochrane D

McClure D J: See Recknold J C

McComas A J: See Vickers J D

McCoy E E: See Enns L

McGovern E: See Zifkin B

McGreal D A: See McMenamin J

McKim H R, Calverley D G, Dewhurst W G: Effect of Nialamide and Tranylcypromine on Rate Whole Brain Concentrations of 5Hydroxytryptamine, Tryptamine and 2-Phenyethylamine, 238 (Aug) Abs See Calverley D G

McLachlan R S, Kaibara M, Girvin J P: The
Relationship Between Focal Penicillin Spikes and Spindles in Cerveau Isole Cats, 324 (Nov) Abs

McLean D R, Nihei T: Biochemical Markers for Huntington's Chorea, 281 (Nov) - See Humphrey J G

McMenamin J, McGreal D A: The Neurological Manifestations of Rhabdomyosarcoma in Childhood, 319 (Nov) Abs

McPhedran R S: See Wortzman D J

McQueen J D: See Polyzoidis K S

Nag S, Robertson D M, Dinsdale H B: Cerebrovascular Permeability in Mechanically Induced Hypertension, 335 (Nov) Abs

Nagata K, Araki G, Mizukami M, Kawase T: Computed Mapping of Electroencephalogram (CME) in Cerebral Infarction; Comparative Study with C T and Regional Cerebral Blood Flow, 321 (Nov) Abs

Negri G: See D'Angelo A

Nestoros J N: GABAergic Mechanisms and Alcoholism, 233 (Aug) Abs

Nethercott J: See Horsey W J

Nevsimalova S: See Broughton $R$

Newfield P, Roizen M, Hosobuchi Y, Adams J E, Lamb S: Reduced Anesthesia Requirement in Patients After Periaqueductal Gray Stimulation, 334 (Nov) Abs

Ng P: See Cottle M K W

Ng Stephen K: Fate of Low Molecular Weight Glycoproteins in Myoblast Cytodifferentiation, 119 (May) Abs

Nicholls D M, Creasy R C, Chin-See M W, Saleem M: Protein Labelling in Dystrophic Hamster Muscle, 114 (May) Abs

Nihei T: See Monckton G

$$
\text { : See McLean D R }
$$

Norman Margaret G: Bilateral Encephaloclastic Lesions In a 26 Week Gestation Fetus: Effect on Neuroblast Migration, 191 (Aug)

Norris J W: See Kolin A - See Vilaghy M I

Noseworthy J H, Heffernan L P M: Motor Radiculopathy - An Unusual Presentation of Multiple Sclerosis, 207 (Aug)

Nudleman K, Watters $G \mathrm{~V}$, O'Gorman A, Hollenberg $R$, Blundell $J$, Rosenblatt $B$, Humphreys P: Neurofibromatosis and Macrocrania-Megalencephaly, 336 (Nov) Abs

Nuttal K: See Ball M J

O'Brien Beth, Jackson R, Tang-Wai R, Lewis A J, Atack E A: Hereditary Sensory Neuropathy: A Case with Pain and Temperature Dissociation, 73 (Feb)

Odusote K: See Matthew E

O'Gorman A: See Nudleman K

O'Gorman G: See Horowitz S

Ogunmekan A 0: Coma in Childhood with Particular Reference to Its Aetiology, Clinical Findings, Mortality, Morbidity and Prognosis, 330 (Nov) Abs

Olanow C W: Failure of Plasmapheresis in PostThymectomy Myasthenia Gravis, 334 (Nov) Abs
See Rothman S J

Olivier A: The Results of Surgical Treatment of Temporal Lobe Epilepsy, A Personal Experience with the First 100 Consecutive Cases, 331 (Nov) Abs

Oss I: See Thompson M W

Ouaknine G E, Mohr G, Hardy J: Assessment of Experimental Microvascular Surgery by Scanning Electron Microscopy, 321 (Nov) Abs See Mohr G

Ovalle W K, Shinn S L: Microscopic Evaluation of Soleus and Extensor Digitorum Longus (EDL) Muscles in Young Dystrophic Mice of the $\mathrm{C} 57 \mathrm{BL} / 6 \mathrm{~J}$ dy $2 \mathrm{~J} / \mathrm{dy} 2 \mathrm{~J}$ Strain, 120 (May) Abs See Slonecker C E

Palmer R B: See Merskey H

Pande S V: See Goswami T

Parfett C L J, Wright J A, Jamieson J C: Selection and Fusion Properties of Concanavalin A - Resistant Myoblast Cell Lines, 119 (May) Abs

Parkinson D: See West M

Parris E: See Sheremata D

Parry D J: Motorneuronal Involvement and Fibre Type Susceptibility in dy2J Mice, 121 (May) Abs

Parvin R: See Goswami T

Pasternac A, Krol R, Peticlerc R, Harvey C, Andermann E, Barbeau A: Hypertrophic Cardiomyopathy in Friedreich's Ataxia: Symmetric or Asymmetric?, 379 (Nov)

Pasutto F M: See Coutts R T

Paty D W, Cousin H K, Bass B: Suppressor Cell Activity and Mitogen Responses in Various Phases and Stages of Multiple Sclerosis (MS), 332 (Nov) Abs

\section{See Ebers G C \\ See Feasby Thomas E \\ See Rice G P A \\ See Warren K G}

Payne F J: See Hugenholtz H

Pecknold J C, McClure D J, Appeltauer L, Allan $T$, Wrzesinski L: Potentiation of Clomipramine by Tryptophan in the Treatment of Agoraphobic and Social Phobic Patients. 228 (Aug) Abs

Peerless S J, Ishikawa R, Hunter I G: Protective Effect of Fluosol in Acute Cerebral Ischemia, 328 (Nov) Abs

Pehowich Enid: See Monckton George

Pelnar Premysl: See Stewart John

Pena S: See Karpati G

Pena S D J: See Wrogemann K

Pena Sergio D J: Cytoskeleton-Membrane Relationships in Normal and Dystrophic Human Fibroblasts, 114 (May) Abs

Percy M E, Trew-Marshall B, Chang L S, Freedman $M$ H, Thompson $M$ W: 45 CA $2^{+} / 3$ H 20 Fluxes in Peripheral Blood Lymphocytes From Duchenne Muscular Dystrophy Carriers, 122 (May) Abs See Stewart P A See Thompson $M$ W 
Perkins C Suzanne, Bray Garth M, Aguayo Albert J: Evidence for Undifferentiated Schwann Cells In the Spinal Roots of Dystrophic Mice, 123 (May) Abs

Carlstedt T, Mizuno K, Aguayo A J: Failure of Regenerating Dorsal Root Axons to Regrow into the Spinal Cord, 323 (Nov) Abs

Peterson Alan C, Frair Pat, Rayburn Helen, Cross David: Dystrophic-Normal Mouse Chimaeras: Extramuscular Influences in the Expression of the Muscle Disease, 123 (May) Abs

See Frair P M

Peterson E W: See Cardosa E R

Peterson M A: See Biggs D F

Peticlerc R: See Pasternac A

Petrali E H, Baker G B, Hiob L E: Central Nervous System Stimulants and the Uptake and Release of Dopamine and p-Tyramine in Rat Striatum in Vitro, 236 (Aug) Abs

Sulakhe Prakash V: Highly Localized Alterations in Endogenous Phosphorylation of Myelin Proteins in Murine Dystrophy, 123 (May) Abs

Philips S R: A Sensitive and Specific Radioenzymatic Assay for Noradrenaline and Adrenaline, 230 (Aug) Abs

Phillis J W, Wu P H: Interactions Between the Benzodiazepines, Methylxanthines and Adenosine, 247 (Aug) See Wu P H

Picard R: See Bouvier G

Pillay N, Blume $\mathrm{W} T$ : Electrographic and Clinical Correlations of Secondary Bilateral Synchrony (SBS), 326 (Nov) Abs

Pivik R T, Hones A M, Bylsma F W: Effects of Vestibular Activation on Smooth Pursuit Tracking Performance in Psychiatric Patients, 233 (Aug) Abs

Pollina C M: See Hudecki M S

Polyzoidis K S, McQueen J D: Extraluminal Dissection with Carotid Endarterectomies, 329 (Nov) Abs

Poortvliet D C J: See Magnus O

Potier M: See Melançon S B

Pourcher E, Barbeau A: Field Testing of an Ataxia Scoring and Staging System, 339 (Nov)

Preston D N: See Benoit B G - See D'Alton J See Grimes J D

Proschek L: See Jasmin G

Purves Sherrill J, Low M D, Galloway Janice, Reeves Bruce: Multimodality Evoked Potential Testing in Multiple Sclerosis, 326 (Nov) Abs Martin W, Evelyn R, Godolphin W: EEG Activity During Barbiturate Administration of Hypoxic Brain Injuries in Adults, 320. (Nov) Abs

Quartey Gilbert R C, Gabriel Youssef H, Tchang Stanley: Chronic Extradural Hematoma Presenting with Subgaleal Mass, 71 (Feb)

Radonjic D: Polyelectromyographic Study of Extrapyramidal Motor Disorders Associated with Neuroleptics, 239 (Aug) Abs
Raso J V: See Allard P

Rathbone M P: See Vickers J D

Rayburn Helen: See Peterson Alan C

Reeves Bruce: See Purves Sherrill J

Rein Glen: See Sandler M

Reveley M A: See Sandler M

Rewcastle N B, Bergeron C: Occurrence of Creutzfeldt-Jakob-like Vacuolar Change in Alzheimer's Disease and Other Conditions, 322 (Nov) Abs

Wortzman G, Holgate R, Kovacs K,

Burrow G: Correlation of Radiologically Abnormal Sellas with Small Pituitary Adenomas in an Unselected Autopsy Series, 319 (Nov) Abs - See Hoffman Harold J See Wherrett $\mathbf{J} \mathbf{R}$

Rice G P A, Paty D W, Ball M J, Tatham R, Kertesz A: Spongiform Encephalopathy of Long Duration: A Family Study, 171 (Aug)

Richards C, Bouchard J P, Bouchard R, Barbeau H: A Preliminary Study of Dynamic Muscle Function in Hereditary Ataxias, 367 (Nov)

Richardson P M: See Holmberg R D

Ridgley B A, Dibkin Barbara, Schwartz M, Tator C H, Rowed D W: The Relationship of a Focal Motor Neurological Deficit to Intellectual Function in External Head Trauma, 320 (Nov) Abs

Riopelle R J, Boegman R J, Cameron D A: Peripheral Nerve Segments Promote Neurite Outgrowth from Embryonic Sensory and Spinal Cord Neurons in Vitro, 322 (Nov) Abs - See Abdollah $\mathbf{H}$

Roberge Andree G: Selective Changes in Brain Amines After Delayed Response (DR) and Successive Discrimination (SD) Learning in Cats, 229 (Aug) Abs

Robert Francoise: See Hausser Chantal O

Robertson D M: See Nag S

Robertson H A, Warenycia $M$ W: Effects of Chronic Amphetamine on Dopamine and Serotonin Receptors, 239 (Aug) Abs

The Benzodiazepine Receptor: The Pharmacology of Emotion, 243 (Aug)

Roizen M: See Newfield P

Rondeau D B: See DiMichele G

Rosenblatt B: See Horowitz S See Hwang $P$

See Nudleman $K$

Rosenmann E: See Wrogemann $K$

Ross R T: C Miller Fisher, 273 (Nov)

Ross-Chouinard Andree: See Chouinard Guy

Roth B: See Broughton R

Roth S H: Anestheties Can Selectively Disrupt the Normal Activity of a Single Isolated Neuron, 232 (Aug) Abs

Rothman S J, Heyman A, Hurwitz B, Rozear $M$ : Down's Syndrome in Families with Alzheimer's Disease, 328 (Nov) Abs

Olanow C W: Brain Stem Glioma: Abrupt Onset of Hemiplegia with Rapidly Progressive Course, 319 (Nov) Abs

Rowed David W, Souri Mahadev K: Intravenous Barbiturates in Comatose Head
Injuries: Late Failure to Control Elevated Intracranial Pressure, 320 (Nov) Abs - See Meguro K See Ridgley B A See Vilaghy $M I$ See Ziganow Sonja

Roy A: Differential Diagnosis of Hysterical Convulsions from Epilepsy, 330 (Nov) Abs

Roy Louis E: Migraines Inhabituelles, 185 (Aug) Rozdilsky B: See MacFadyen D J

Rozear M: See Rothman S J

Rudelli R D: See Vilaghy M I

Russell Neville A, Maroun F B: Spinal Subdural Hematoma, 326 (Nov) Abs

St. Hilaire J M: See Bouvier G

Sabet Laila M: Bilateral Symmetrical Brain Lesions in Tricyclic Antidepressant Overdosage, 305 (Nov)

Saleem M: See Nicholls D M

Salloum A: See Lapointe L R

Sandler M, Carter Susan Bonham, Reveley $M$ A, Glover Vivette, Rein Glen: Further Light on the Tyramine Test in Depression, 265 (Aug)

Saunders Fraser $\mathbf{W}$ : Scar Prevention in Peripheral Nerve Surgery, 221 (Aug)

Saxena Bishan: See Grof Eva

Sazant A: See Sheremata W

Schatz S W, Banna M: Trans-Sphenoidal Adenography, 322 (Nov) Abs

Schmidek H H: Management of Severe Head Injuries with Barbiturate Protocol, 335 (Nov) Abs

Schut Luis: See Bruce Derek A

Schutz Hart, Fleming J F R, Humphreys R P, Deck J H N, Keith William S: University of Toronto Neurosurgical Rounds No. 3. Normal Pressure Hydrocephalus - High Pressure Normocephalus, 211 (Aug)

Schutz H, Taylor F: CSF Dynamics in Adults with Hydrocephalus, 332 (Nov) Abs

Schwartz Michael L: A Practical Flow Chart for the Management of Patients with Head Injuries, 319 (Nov) Abs

$$
\text { See Ridgley B A }
$$

Seggie J: Chlordiazepoxide Normalizes Abnormal Behavior and Hormone Response to Stress in Septal Rats, 234 (Aug) Abs

Seland T P: See Becker W J

Sells Bruce H: See Bag Jnanankur

Seshia S S, Johnston B, Kasian G: Prediction of Outcome in Non-traumatic Coma in Childhood, 333 (Nov) Abs

Shader Richard I: See Greenblatt David J

Shapcott D: See Draper $P$

Sharpe James A, Lo Alex W: Cerebral NonVisual Control of the Vestibulo-Ocular Reflex, 327 (Nov) Abs

$$
\text { See White Owen B }
$$

Sheppard Ann: See Kertesz Andrew

Sheremata W, Sazant A, Parris E: Cerebrospinal Fluid (CSF) Catalase in Multiple Sclerosis, 323 (Nov) Abs

Sherwin A: See Andermann E

Sherwin A L: See Matthew E 
Shinn S L: See Ovalle W K

Shivers Richard R, Atkinson Burr G: Intramembrane Architecture of Dystrophic Murine Skeletal Muscle Sarcolemma; A FreezeFracture Study, 122 (May) Abs See Atkinson Burr G

Shumak K H: See Humphrey J G

Sibley William A: See Bamford Colin R

Silverman H, Charlton M P. Atwood H L: Measurement of Intracellular Ionic Activity in Normal and Dystrophic Mouse Muscle Using Ion Selective Microelectrodes, 12I (May) Abs

Sima Anders A F: See Curry Bernadette

Singer S: See Keene D L

Slonecker C E, Ovalle W K, Bressler B H, Jasch L G: Studies on Thymic Influences in Genetic Muscular Dystrophy in Mice, 124 (May) Abs

Smith Michael S, Laguna Jose F: Confusion, Dysphasia, and Asterixis Following Metrizamide Myelography, 309 (Nov) - See Bamford Colin R

Souri Mahadev K: See Rowed David W

Sourkes T L, Gagner J P, Gauthier S: Neural Components of the Response to Stressors: Central Pathways Mediating the Induction of Adrenal Tyrosine Hydroxylase, 229 (Aug) Abs

Sproule Brian: See Bornstein Robert

Steinbok P, Mahaley M S, Bigner R U, Bigner $D$ : Radiotherapy and Chemotherapy in the Treatment of Gliomas: An Experimental Study, 335 (Nov) Abs

Stewart John, Pelnar Premysl: Does the Use of Chain-Saws Produce Neuropathy in Canadian Forestry Workers, 322 (Nov) Abs

Stewart P A, Percy M E, Chang L, Thompson M W: CK Isozyme Transition in Developing Skeletal Muscle of Normal and Dystrophic chick Embryos, 116 (May) Abs

Stilwell G A: See MacFadyen D J

Stoyka W W, Tucker W W: The Effects of Mannitol on the Cerebral Cardiac and Pulmonary Circulations in Neurosurgical Patients, 334 (Nov) Abs

Stratford J G: See Holmberg R D See Matthew E

Surbak-Sharpe J: See Warren K G

Sugita Y: See Broughton R

Sulakhe Prakash V: See Petrali Elena $H$

Sussman P S, LaPierre Y D: A Method of Statistical Analysis of the AMDP Psychopathology Rating Scale Based on the Results of a Two Year Study of Two Long-Acting Neuroleptics in Chronic Schizophrenics, 239 (Aug) Abs

Sutherland L R: See Becker W J

Swanson J M: See Logan W J

Szewczuk Myron R: Abnormal Age-Associated Immunoregulation in Muscular Dystrophic Mice, 124 (May) Abs

Tang-Wai R: See $O^{\circ}$ Brien Beth

Tatham R: See Rice G P A

Tator Charles H, Edmonds Virginia E, Andrews David F: Relationships Between Cord Injury, Spinal Column Injury and Recovery in 358 Spinal Cord Injured Patients, 324 (Nov) Abs
See Meguro K

See Ridgley B A

Taylor F: See Schutz H

Tchang Stanley: See Quartey Gilbert R C

Teasdall Robert D, Van Den Ende H: Some EMG Observations on Crossed Reflex Activity in Humans, 326 (Nov) Abs

TerBrugge K: See Yufe R S

Thiry P S: See Allard P

Tibbles J A R: See Camfield P R See Meek D C

Thompson $\mathbf{M} \mathbf{W}$, Andrews D F, Chang L S, Lapczak L, Oss I, Percy M E: A Combination of Four Serum Tests for Duchenne Muscular Dystrophy Carrier Detection, 115 (May) Abs See Percy M E See Stewart P A

Thompson R G: See Wrogemann K

Thomson C M: See Dryden W F

Tolis G, Mehta A, Andermann E, Andermann F, Barbeau A: Friedreich's Ataxia and Glucose Tolerance II. The Effect of Ingested Glucose on Serum Growth Hormone in Homozygotes, Obligate Heterozygotes and Potential Carriers of the Friedreich's Ataxia Gene, 401 (Nov)

Mehta A, Andermann E, Harvey C, Barbeau A: Friedreich's Ataxia and Glucose Tolerance I. The Effect of Ingested Glucose on Serum Glucose and Insulin Values in Homozygotes, Obligate Heterozygotes and Potential Carriers of the Friedreich's Ataxia Gene, 397 (Nov)

Trew-Marshall B: See Percy M E

Trites R L, Blouin A, Brants T: Prediction of Response of Hyperactive Children to Methylphenidate, 333 (Nov) Abs - See Bornstein R

Tsaros Linda: See Kaplan Ronald

Tucker W S: See Wortzman D J

Tucker W W: See Stoyka W W

Tunnicliff Godfrey, Matheson G Keith: Postmortem Increases in GABA Receptor Binding to Membranes of Cat Central Nervous System, 19 (Feb) : See Botez M 1

Turnbull I M: Percutaneous Lumbar Rhizotomy for Spasms in Paraplegia, 330 (Nov) Abs

Upton A R M, Cermak T, Amin I, Cooper I S: Clinical Applications of Subcortical Somatosensory Evoked Responses, 334 (Nov) Abs

Uziel G: See Bertagnolio B See D'Angelo A

Vanasse Michel: See Brakier-Gingras Lea See Melançon S B

Van Den Ende H: See Teasdall Robert D

Vanderwolf $\mathbf{C ~} \mathbf{H}$ : Evidence that a Trace Amine is Essential for the Operation of a BehaviorCorrelated Reticular Formation Input to the Neocortex, 228 (Aug) Abs

Van Der Wulp C J M: See Magnus O Van Gelder $\mathbf{N}$ M: See Janjua $\mathbf{N}$ Aslam Van Huffelen A C: See Magnus O
Van Petten G R: See Cottle M K W

Ventureyra E C G, DaSilva V F: Management of Vascular and Tumoural Lesions of the Pineal Region in Children, 332 (Nov) Abs

Vezina C: See Huang $Y S$

Vickers J D, Fraenkel D, McComas A J, Rathbone M P: The Effect of Phenytoin on Membrane Protein Phosphorylation in Patients with Myotonic Muscular Dystrophy, 125 (May) Abs

Vilaghy M I, Hachinski V C, Norris J W, R.udelli R D, Cooper P W: Blood Flow Characteristics of the Extra-Cerebral Circulation, 329 (Nov) Abs

Rowed D W, Hachinski V C, Norris J W: Neurosurgical Applications of Doppler, 320 (Nov) Abs

Villemure J G, Bertrand G: Akinetic Mutism: Contributing Dynamic Factors, 336 (Nov) Abs

Vinuela F: See Fox A

Vrancart C: See Murphy E G

Waldron G: See Baker J M

Warencyia $M$ W: See Robertson H A

Warren K G, Lewis M L, Brown S M, SubakSharpe J, Young B, Zbitneau A, Paty D W, Kettyls G D: Herpes Simplex Virus Encephalitis Isolates Analyzed by Restriction Endonucleases, 330 (Nov) Abs See Lewis Marcia E See Young G B

Warsh J J, Godse D D, Li P, Cheung S: Significance of 3,4-Dihydroxyphenlethylene Glycol (DHPG) Formation in CNS Norepinephrine Metabolism, 230 (Aug) Abs

Watters G: See Hwang $P$

Watters G V: See Keene D L See Nudleman K

Watts A R: See Boyd Michael

Weir B: Mechanisms of Growth of Chronic Subdural Hematomas - Is a Fluid Shift Involved?, 334 (Nov) Abs

Menon D: Clinical Applications of Inhalational Xenon 133 for the Study of Regional Cerebral Blood Flow, 321 (Nov) Abs

Welner S A: See Matthew E

Wenger B: See Johnson D D

Weselake Randall J: See Jacobs Hans K

West G R: See Becker W J

West M, Parkinson D, Havlicek V: Spectral Analysis of the Electroencephalographic Response to Experimental Concussion in NonAnesthetized Rats, 320 (Nov) Abs

Wheelock $W$ Brian, Holness $R$ O: Postoperative Tension Pneumocephalus, 328 (Nov) Abs

Wherrett J R, Huterer S, Khan M, Rewcastle N B: Cerebral Phospholipidosis ExperimentallyInduced with Chlorphentermine, 328 (Nov) Abs

White Owen B, Sharpe James A: Retinal Nerve Fibre Atrophy in Compression of the Chiasm - a Prognostic Sign, 327 (Nov) Abs

Wilder B J: See Bruni J

Wilkins A: See Zifkin B 
Wilson Charles B: See Fulton Dorcas S

Wong P, Barbeau A: Protein Kinase Activity of Human Erythrocyte Membranes in Friedreich's Ataxia, 425 (Nov)

Wong $\mathbf{P} \mathbf{K} \mathbf{H}$, Bickford R G: Brainstem Auditory Evoked Potential (BAEP) - The Importance of Noise, 325 (Nov) Abs

Wong Uiu C: See Murphy John T

Wood J D: Use of a Synaptosomal Model to Monitor Drug-Induced In Vivo Changes in the y-Aminobutyric Acid Content of Nerve Endings and its Relevance to Research on Antipsychotic Drugs, 253 (Aug)

Woodhurst W B: Cerebellar Infarction Review of Recent Experiences, 97 (May)

Wort J: See Meek D C

Wortzman D J, Tucker W S, Finlayson D M, McPhedran R S, Gershater R: Subdural Empyema with Negative C T Scan: A Case Report, 67 (Feb)

Wortzman G: See Rewcastle N B
Wright J A: See Parfetti C L J

Wrogemann K, Thompson R G, Rosenmann E, Pena S D J: Searching for the Abnormal Gene Product(s) in Fibroblasts from Patients with Duchenne Muscular Dystrophy, 114 (May) Abs

Wrzesinski L: See Pecknold J C

Wu P H, Phillis J W: Specific Binding of 3 H-2-Chloroadenosine to Rat Brain Cortical Membranes: Adenosine Receptors, 239 (Aug) Abs : See Phillis J W

Yates S K: See Brown W F

Yeung C M: See Murphy E G

York Ernest: See Bornstein Robert

Young B: See Warren K G

Young G B, Blume W T, Bolton C F, Warren K G: Anaesthetic Barbiturates in Refractory Status Epilepticus, 291 (Nov)

Young S N, Gibson C J, Deikel S M, Binik Y M:
Behavioral and Biochemical Effects of Tryptophan, Tyrosine and Pheylalanine in Mice, 229 (Aug) Abs - See Gauthier S

Yu P H: The Multiplicity of Monoamine Oxidase: Molecular Aspects, 237 (Aug) Abs

Yufe R S, Hyde M L, TerBrugge K: Auditory Evoked Responses and Computerized Tomography in Centra! Pontine Myelinolysis, 297 (Nov)

Zak Cynthia: See Bornstein Robert

Zbitneau A: See Warren K G

Zifkin B, Andermann F, McGovern E, Wilkins A: Seizures Precipitated by Mental Arithmetic, 330 (Nov) Abs

Ziganow Sonja, Rowed D W: The Cortical Somatosensory Evoked Potential in Acute Spinal Cord Injuries, 323 (Nov) Abs 


\title{
Subject Index to Volume 7
}

\author{
Abs $=$ Abstract
}

Acetomiophen

overdose and cerebral edema, 302 (Nov) Abs

Adenography

trans-sphenoidal, 322 (Nov) Abs

Adenosine

and benzodiazepines, 247 (Aug)

and methylxanthines, 247 (Aug)

Adenosine Receptors

and binding of chloroadenosine, 239 (Aug)

Abs

Adrenal Tyrosine Hydroxylase

central pathways mediating the induction of, 229 (Aug) Abs

Adrenaline

radioenzymatic assay, 230 (Aug) Abs

Akinetic Mutism

contributing dynamic factors, 336 (Nov) Abs

Alcohol

maternal-fetal exchange, 236 (Aug) Abs

Alcoholism

GABAergic mechanisms and, 233 (Aug) Abs

Alzheimer's Disease

cerebral organic changes and psychological measurements, 45 (Feb)

Down's Syndrome and, 328 (Nov) Abs

familial, 51 (Feb)

with Creutzfeldt-Jacob vacuolar changes, 322 (Nov) Abs

with features of Creutzfeldt-Jakob Disease, 51 (Feb)

Amines

brain and learning, 229 (Aug) Abs

hydroxylated and isolation and quantitation of, 236 (Aug) Abs

Amitriptyline

cerebral pathology, 305 (Nov)

Amyotrophy

distal and familial ataxia, 345 (Nov)

Aneurysm

posterior inferior cerebellar artery in child, 301 (Nov)

Aneurysms

carotid ophthalmic, 231 (Nov) Abs

Angiograms

cerebral and TlAs, 9 (Feb)

Antibodies

in the detection of mitochondrial creatine kinases, 116 (May) Abs

Anticonvulsant Drugs

life threatening complications, 325 (Nov) Abs

Antidepressant Medication

overdosage, 305 (Nov)

tricyclic, 305 (Nov)

Antipsychotic Drugs

and GABA content of nerve endings, 253 (Aug)

Anxiolytic Drug Therapy

pharmacokinetic aspects of, 269 (Aug)

Artery

aneurysm, 301 (Nov)

paradoxical infarction, 313 (Nov)

posterior inferior cerebellar, 301 (Nov)

vertebral, 313 (Nov)
Asparagine

and cerebral amino acid neurotransmitters, 447 (Nov)

Aspartate

and 3-acetyl pyridine ataxia in rats, 451 (Nov)

Asterixis

and metrizamide myelography, 309 (Nov)

Ataxia

dynamic muscle function, 367 (Nov)

familial and progressive, 345 (Nov)

field testing, 339 (Nov)

from 3-acetyl pyridine in rats, 45I (Nov)

hereditary, 367 (Nov)

hereditary and leucocyte glutamate dehydrogenase, 421 (Nov)

leucocyte glutamate dehydrogenase and, 332 (Nov) Abs

scoring and staging system of, 339 (Nov)

tremor and distal amyotrophy, 345 (Nov)

Atropine

and response of cortical neurones to acetylcholine, 231 (Aug) Abs

Auditory Evoked Responses

central pontine myelinolysis, 297 (Nov)

Avian

dystrophy and thymic mast cells, 124 (May)

Abs

Axons

dorsal root regeneration, 323 (Nov) Abs

Balint's Syndrome

157 (May)

Barbiturates

in refractory status epilepticus, 291 (Nov)

Behavior Disturbances

treatment by hemispherectomy, 33 (Feb)

Benzodiazepine Receptor

and the pharmacology of emotion, 243 (Aug)

Benzodiazepines

and methylxanthines and adenosine, 247 (Aug)

Beta-Amino Acid Transport

in Friedreich's Ataxia, 441 (Nov)

Biofeedback

EMG in patients with motor disorders, 199 (Aug)

Brain

lesion from tricyclic antidepressant overdosage, 305 (Nov)

Brain Injury

EEG activity and barbiturate coma, 320 (Nov) Abs

neurological deficit and intellectual function, 320 (Nov) Abs

\section{Caffeine Contracture Test}

histochemical profile of muscle and, 327 (Nov) Abs

Calcium

dependent neutral proteinase, 114 (May) Abs hamster muscle, 114 (May) Abs

Canadian College of Neuropsychopharmacology 227 (Aug)
Canine Hypomyelinating Disorder

328 (Nov) Abs

Cardiomyopathy

hamster, 435 (Nov)

hypertrophic in Friedreich's Ataxia. 379 (Nov)

morphology of in Friedreich's Ataxia, 389 (Nov)

prevention by verapamil, 114 (May) Abs

Carotid

endarterectomy and monitoring, 321 (Nov) Abs

Carotid Endarterectomy

extraluminal dissections, 329 (Nov) Abs

monitoring and internal shunt, 326 (Nov) Abs

neuropsychological assessment of, 329 (Nov) Abs

Carpal Tunnel Syndrome

$256 \mathrm{~Hz}$ vibration, 324 (Nov) Abs

Caudate Nucleus

Huntington's disease cellular changes, 87 (May)

Central Pontine Myelinolysis

auditory evoked responses, 297 (Nov)

C T Scan, 297 (Nov)

Cerebellar

infarction, 97 (May)

Cerebral

albumin and water dynamics and hyperosmolar solutions, 334 (Nov) Abs

Cerebral Blood Flow

and arterial vasospasm in subarachnoid hemorrhage, 321 (Nov) Abs

and EEG in normals, 195 (Aug)

compared with $\mathrm{C} T$ in cerebral infarction, 321 (Nov) Abs

inhalational xenon 133, 321 (Nov) Abs

Cerebral Function

chronic lung disease, 293 (Nov)

Cerebral Ischemia

plasma and erythrocyte flow in, 329 (Nov) Abs protection from fluosol, 328 (Nov) Abs

Cerebral Organic Changes

in Alzheimer's Disease, 45 (Feb)

Cerebral Phospholipidosis

induced by chlorphentermine, 328 (Nov) Abs

Cerebral Symptoms

metrizamide myelography, 309 (Nov)

Cerebrospinal

fluid fistula and osteolysis, 39 (Feb)

Cerebrospinal Fluid

catalase in multiple sclerosis, 323 (Nov) Abs

Cervical Spine

internal fixation with interlaminar clamp. 329 (Nov) Abs

stabilization and the anterior approach, 329 (Nov) Abs

Chiasm

and retinal nerve fiber atrophy, 327 (Nov) Abs

Chick

acetylcholinesterase activity, 118 (May) Abs dystrophic cultured muscle, 118 (May) Abs influence of neural extracts, 118 (May) Abs

Chick Embryos 
normal and dystrophic isozyme transition in muscle of. 116 (May) Abs

\section{Chicken}

dystrophy and drug therapy screening, 124 (May) Abs

dystrophy and myelination in a peripheral nerve, 122 (May) Abs

\section{Chlorpromazine}

chromatographic determination and its metabolites in plasma, 235 (Aug) Abs

Chronic Lung Disease

cerebral function, 293 (Nov)

venesection, 293 (Nov)

\section{Clomipramine}

and tryptophan, 228 (Aug) Abs

Coma

in childhood, 330 (Nov) Abs

prediction of outcome in children, 333 (Nov) Abs

Concavalin A

selection and fusion properties of and resistant myoblast cell lines, 119 (May) Abs

\section{Concussion}

experimental and the EEG response, 320 (Nov) Abs

Convulsion

and kindling, 59 (Feb)

kindling, 223 (Aug)

Corneomandibular Reflex

clinical value of, 327 (Nov) Abs

Creatine Kinase

mitochondrial, 116 (May) Abs

Creutzfelt-Jakob Disease

familial and of long-duration, 171 (Aug)

pathology of in familial dementia of Alzheimer's type, 51 (Feb)

CSF

electrophoresis, 275 (Nov)

C T Scan

Alzheimer's Disease, 45 (Feb)

cerebellar infarction, 97 (May)

central pontine myelinolysis, 297 (Nov)

EEG, 45 (Feb)

subdural empyema, 67 (Feb)

Cultured Cells

biochemical studies of in Friedreich's Ataxia, 409 (Nov)

Cysticercosis

cerebral, 319 (Nov) Abs

Cytomegalovirus

Hutington's disease, 87 (May)

D'Anville

1 (Feb)

Dementia

familial of Alzheimer's type, 51 (Feb)

Demyelinating Activity

passive transfer of in allergic neuritis and Guillain-Barre polyneuropathy, 116 (May) Abs

\section{Depression}

desipramine, 228 (Aug) Abs

kynurenine excretion, 238 (Aug) Abs

MHPG, 227 (Aug) Abs

noradrenergic function, 267 (Aug)

seasonal variation in post-partum, 238 (Aug) Abs

tyramine test, 265 (Aug)
Dermatoglyphic

alterations and anticonvulsant effects on the fetus, 325 (Nov) Abs

Desipramine

in depressed patients, 228 (Aug) Abs

Diabetes

autonomic neuropathy and, 135 (May)

streptozotocin in the rat, 135 (May)

Dopamine

in rat striatum, 236 (Aug) Abs

neurotoxicity and the pathogenesis of Parkinson's disease, 235 (Aug) Abs

platelets Huntington's chorea, 281 (Nov)

Dopamine Receptors

chronic amphetamine on, 239 (Aug) Abs

Doppler

carotid imaging, 321 (Nov) Abs

neurosurgical applications, 320 (Nov) Abs

Down's Syndrome

compared to normal aging and Alzheimer's dementia, 336 (Nov) Abs

platelets and, 238 (Aug) Abs

serotonin uptake in, 238 (Aug) Abs

Drugs

anti-epileptic, 330 (Nov) Abs

carbamazine, 330 (Nov) Abs

phenytoin, 330 (Nov) Abs

Duchenne Muscular Dystrophy

abnormal gene products in fibroblasts, 114 (May) Abs

carrier and changes in peripheral blood lymphocytes, 122 (May) Abs

carrier detection, 115 (May) Abs

cytoskeleton defect of fibroblasts, 115 (May)

fibroblast polysome activity of patients and carriers with, 115 (May) Abs

orthopedic aspects of, 116 (May) Abs

penacillamine in the management of, 120

(May) Abs

preclinical stage, 115 (May) Abs

serum tests for, 115 (May) Abs

DuVal

1 (Feb)

Dystrophic Diaphragm

2,4 dinitrophenol, 114 (May) Abs

Dystrophy

chick embryo, 118 (May) Abs

chicken and oral phenytoin, 120 (May) Abs

facio scapulo humeral in infants, 333 (Nov) Abs

mouse and isometric contractile properties of, 121 (May) Abs

mouse and microscopic evaluation of muscles, 120 (May) Abs

protein synthesis in, 118 (May) Abs

\section{EC/IC Bypass Study}

327 (Nov) Abs

\section{Edema}

malignant brain in children, 335 (Nov) Abs

Education

neurosurgical, 328 (Nov) Abs

EEG

and cerebral blood flow in normals, 195 (Aug) and secondary bilateral synchrony, 326 (Nov) Abs

CT Scan and Alzheimer's disease, 45 (Feb) in juvenile diabetes, 330 (Nov) Abs spectral analysis of in space occupying lesions, 333 (Nov) Abs
Electrophoresis

CSF, 275 (Nov)

EMG

biofeedback in patients with motor disorders, 199 (Aug)

Emotion

the benzodiazepine receptor, 243 (Aug)

the pharmacology of, 243 (Aug)

Encephaloclastic Lesions

in a 26 week gestation fetus, 191 (Aug)

Encephalopathy

long-duration familial, 171 (Aug)

spongiform, 171 (Aug)

End-Plate Activity

333 (Nov) Abs

Enzymes

cholinergic, 133 (May)

dietary folic acid, 133 (May)

GABA, 133 (May)

Epilepsy

chronic focal in childhood tumors, 331 (Nov) Abs

forms of temporal lobe, 325 (Nov) Abs

plasma amino acids in, 328 (Nov) Abs

serotonin metabolism in, 326 (Nov) Abs

status and anesthetic barbiturates, 291 (Nov)

surgical and electronic instrumentation for, 325 (Nov) Abs

temporal and surgical treatment, 331 (Nov) Abs

treatment by hemispherectomy, 33 (Feb)

Erythrocyte

cholesterol acyltransferase activity in Friedreich's Ataxia, 429 (Nov)

fatty acid composition in Friedreich's Ataxia, 429 (Nov)

lecithin in Friedreich's Ataxia, 429 (Nov)

phospholipids in Friedreich's Ataxia, 429 (Nov)

Erythrocyte Membranes

in Friedreich's Ataxia, 425 (Nov)

protein kinase activity of, 425 (Nov)

\section{Evoked Responses}

aberrant waveforms from pattern reversal stimulation, 326 (Nov) Abs

brainstem auditory and noise, 325 (Nov) Abs clinical application of, 334 (Nov) Abs

multimodality in multiple sclerosis, 326 (Nov) Abs

somatosensory in acute spinal cord injuries, 323 (Nov) Abs

visual and auditory in spinal cord disease, 324 (Nov) Abs

Experimental Allergic Neuritis

passive transfer of demyelinating activity, 116 (May) Abs

Extracerebral Circulation

blood flow characteristics of, 329 (Nov) Abs

Extrapyramidal

symtpom rating scale, 233 (Aug) Abs

Extrapyramidal Nuclei

GABA-containing neurons, 251 (Aug)

\section{Fibroblasts}

abnormal gene products in, II4 (May) Abs cytoskeleton defect in Duchenne Muscular Dystrophy, 115 (May) Abs

dystrophic human cytoskeleton-membrane relationships, 114 (May) Abs protein synthesis of polysomes from in 
Duchenne Muscular Dystrophy, 115 (May) Abs

Fisher C Miller

an appreciation, 273 (Nov)

Fistula

cerebrospinal fluid and cranial osteolysis, 39 (Feb)

5-Hydroxytryptamine

and gas chromatograph technique, 237 (Aug) Abs

and nialamide and tranylcypromine, 238 (Aug) Abs

\section{Fluphenazine}

plasma level and rubber stoppers used in vacutainers, 235 (Aug) Abs

radioimmunoassay in human plasma, 235 (Aug) Abs

\section{Folic Acid}

cholinergic enzymes, 133 (May)

GABA, 133 (May)

\section{Friedreich's Ataxia}

beta-amino acid transport, 331 (Nov)

biochemical studies in cultured cells, 409 (Nov)

biochemical studies of, 359 (Nov)

cardiomyopathy pathology, 389 (Nov)

cholesterol acyltransferase activity of, 429

(Nov)

clinical and biochemical survey, 351 (Nov)

erythrocyte membranes, 425 (Nov)

erythrocyte phospholipids, 429 (Nov)

fatty acid composition of, 429 (Nov)

glucose tolerance, 397 (Nov), 401 (Nov)

glycosylated hemoglobins in, 405 (Nov)

hypertrophic cardiomyopathy, 379 (Nov)

in northern Italy, 359 (Nov)

lecithin, 429 (Nov)

mechanisms and management of, 383 (Nov)

overview, 455 (Nov)

phosphatidylcholine therapy and, 413 (Nov)

platelet function, 417 (Nov)

protein kinase activity of erythrocytes, 425

(Nov)

serum lipoamide dehydrogenase and, 413 (Nov)

south of ltaly, 351 (Nov)

\section{GABA}

and a synaptosomal model to monitor changes, 253 (Aug)

cat central nervous system, 19 (Feb)

content of nerve endings and antipsychotic drugs, 253 (Aug)

neurones and extrapyramidal nuclei, 251 (Aug)

neuropsychiatric disorders, 257 (Aug)

post-mortem changes in, 19 (Feb)

receptor binding, 19 (Feb)

\section{GABA Enzymes}

and brain cholinergic enzymes, 133 (May)

and dietary folic acid, 133 (May)

Gamma-Hydroxybutyrate

narcolepsy/cataplexy, 23 (Feb)

nocturnal administration of, 23 (Feb)

sleep/waking patterns, 23 (Feb)

Giant Axonal Neuropathy

visual and oculomotor deficits, 177 (Aug)

Glioma

brainstem, 319 (Nov) Abs

Gliomas

radiotherapy and chemotherapy in treatment, 355 (Nov) Abs
Glucose Tolerance

in Friedreich's Ataxia, 397 (Nov), 401 (Nov)

Glutamate

on 3-acetyl pyridine ataxia in rats, 451 (Nov)

Glutamate Dehydrogenase

in leucocytes of hereditary ataxias, 421 (Nov)

Glutamine

and cerebral amino acid neurotransmitters, 447 (Nov)

Guillain-Barre Polyneuropathy

passive transfer of demyelinating activity, 116 (May) Abs

Halifax

1 (Feb)

Hamster

cardiomyopathic, 435 (Nov)

Head Injuries

and barbiturates, 335 (Nov) Abs

barbiturate and intracranial pressure, 320 (Nov) Abs

management of, 319 (Nov) Abs

Hematoma

extradural presenting as subgaleal mass, 71 (Feb)

\section{Hemispherectomy}

behavior disturbances, 33 (Feb)

treatment of epilepsy, 33 (Feb)

Hemoglobins

glycosylated and Friedreich's Ataxia, 405 (Nov)

Hemorrhage

intracranial and anticoagulants, 320 (Nov) Abs

intraventricular and posterior fossa aneurysm, 301 (Nov)

\section{Hereditary}

sensory neuropathy, 73 (Feb)

Hereditary Muscular Dystrophy

avian, 117 (May) Abs

physiological and structural comparison of affected and spared muscles in, 117 (May) Abs

Herpes Simplex Virus

isolates and endonucleases, 330 (Nov) Abs

Herpes Zoster Mandibularis 153 (May)

Horner's Syndrome

in multiple sclerosis, 65 (Feb)

Huntington's Chorea

biochemical markers, 281 (Nov)

Huntington's Disease

immunohistochemical study of, 87 (May)

Hydrocephalus

CSF dynamics in, 332 (Nov) Abs

in relation to birth weight, 331 (Nov) Abs

management of intra-uterine, 332 (Nov) Abs normal pressure, 211 (Aug)

Hydroxyphenylacetic Acids

regional distribution of in rat brain, 234 (Aug) Abs

Hyperactive Children

response to methylphenidate, 333 (Nov) Abs

Hypertension

cerebrovascular permeability and, 335 (Nov) Abs

Hysteria

versus convulsions and epilepsy, 330 (Nov) Abs
Imipramine

and response of cortical neurones to acetylcholine, 231 (Aug) Abs

Immunohistochemistry

in Huntington's disease, 87 (May)

Infarction

cerebellar, 97 (May)

vertebral artery, 313 (Nov)

Inherited Diseases

allelism in clinical variants of, 115 (May) Abs

Injury

injection of peripheral nerves, 143 (May)

Insulin

and cerebral amino acid neurotransmitters, 447 (Nov)

Intracranial Aneurysm

early versus delayed repair, 330 (Nov) Abs

Intracranial Pressure

in head injury, 319 (Nov) Abs

monitoring, 319 (Nov) Abs

Intracranial Surgery

seizures following, 285 (Nov)

Italy

Friedreich's Ataxia in, 351 (Nov)

northern and Friedreich's Ataxia, 359 (Nov)

Jacksonian March

physiological basis for, 79 (May)

Jargon

anatomy of, 325 (Nov) Abs

Kindling

interference by various frequencies, 223 ( $\mathrm{Aug}$ )

$1 \mathrm{~Hz}$ interference, 59 (Feb)

Leucocyte

glutamate dehydrogenase in hereditary ataxia, 421 (Nov)

Leucoencephalopathy

treatment with anti-DNA virus agents, 326 (Nov) Abs

Lipoamide Dehydrogenase Activity

in Friedreich's Ataxia, 413 (Nov)

Lissencephalopathy

and C T Scan, 323 (Nov) Abs

Lithium

neuroendocrine investigations, 228 (Aug) Abs

Lymphomas

primary central nervous system, 333 (Nov) Abs

Macrocrania

megalencephaly and neurofibromatosis. 336 (Nov) Abs

Malignant Hyperthermia post-operative symptoms of, 327 (Nov) Abs

Mandibularis

herpes zoster, I53 (May)

Mannitol

cerebral, cardiac and pulmonary circulations and, 334 (Nov) Abs

March

Jacksonian, 79 (May)

nested ring organization of cortex, 79 (May)

Medulloblastoma

recurrence and treatment with cyclophosphamide, 331 (Nov) Abs

Melanosis

oculodermal and multiple intracranial tumors, 101 (May) 


\section{Membranes}

GABA receptor binding to, 19 (Feb)

\section{Mental Disorders}

trace amines, 261 (Aug)

Meningo-Ependymitis

in Whipple's disease, 163 (May)

Methylxanthines

and adenosine, 247 (Aug)

Metoclopramide

extrapyramidal complications of, 331 (Nov) Abs

Metrizamide

myelography and complications, 309 (Nov)

Microvascular Surgery

and scanning electron microscope, 321 (Nov) Abs

scanning electron microscopy, 329 (Nov) Abs

\section{Migraine}

late-life, 9 (Feb)

unusual, 185 (Aug)

versus transient ischemic attacks, 9 (Feb)

with hyperlipidemia, 185 (Aug)

with Renaud's disease, 185 (Aug)

Mitochondria

from skeletal and cardiac muscles, 120 (May) Abs

\section{Mitochondrial}

creatine kinase, 116 (May) Abs

Molindone

on mouse striatal tyramine, 229 (Aug) Abs

Monoamine Oxidase

molecular aspects, 237 (Aug) Abs

Motor Function

quantitative analysis of, 333 (Nov) Abs

Motor Radiculopathy

in multiple sclerosis, 207 (Aug)

Mouse

dystrophy and alterations of myelin protein, 123 (May) Abs

dystrophy and distribution of protein in muscle, 121 (May) Abs

dystrophy and immunochemical protein analysis, 121 (May) Abs

dystrophy and immunoregulation, 124 (May) Abs

dystrophy and intracellular ionic activity, 121 (May) Abs

dystrophy and motor neuronal involvement, 121 (May) Abs

dystrophy and normal chimaeras and extramuscular influences, 123 (May) Abs

dystrophy and possible immunocyte involvement in, 124 (May) Abs

dystrophy and thymic influences, 124 (May) Abs

dystrophy and undifferentiated Schwann Cells in the spinal root of, 123 (May) Abs

dystrophy intramembrane architecture of skeletal muscle, 122 (May) Abs

dystrophy membrane fluidity in, 122 (May) Abs

Moya-Moya Disease

321 (Nov) Abs

Muscle Function

in hereditary ataxia, 367 (Nov)

Multiple Sclerosis

CSF electrophoresis, 275 (Nov)

familial and optic neuritis, 332 (Nov) Abs

Horner's syndrome, 65 (Feb) motor radiculopathy, 207 (Aug)

neurobehavioral dysfunction, 323 (Nov) Abs

spinal cord swelling, 324 (Nov) Abs

suppressor cell activity and, 332 (Nov) Abs

Muscle

avian and neurones in embryonic enzymic patterns, 117 (May) Abs

avian brachial and embryonic development, 117 (May) Abs

control of cell growth and amino acid transport, 119 (May) Abs

cultured dystrophic and electrophysiological development, 119 (May) Abs

cutured skeletal and protein turnover, 119 (May) Abs

dystrophic hamster and protein labelling, 114 (May) Abs

dystrophic synthesis of plasma membrane proteins, 118 (May) Abs

single monolayer culture free and bound amino acids, 118 (May) Abs

skeletal fibers and gene product distribution, 123 (May) Abs

Muscular Dystrophy

Fifth National Scientific Workshop, 109 (May)

hereditary, 109 (May)

Myasthenia Gravis

failure of plasmapheresis in post-thymectomy, 334 (Nov) Abs

plasma exchange and, 334 (Nov) Abs

Myelography

metrizamide and complications, 309 (Nov)

Myoblast

cytodifferentiation and low molecular weight glycoproteins, 119 (May) Abs

Myopathy

centronuclear and lipofuscin accumulation, 332 (Nov) Abs

Myotonic Muscular Dystrophy

and phenytoin on membrane protein, 125 (May) Abs

zinc deficiency and essential fatty acid deficiency, 125 (May) Abs

Naevus of Ota

multiple intracranial tumors, 101 (May)

Narcolepsy

socio-economic and life effects of, 333 (Nov) Abs

\section{Narcolepsy-Cataplexy}

gamma-hydroxybutyrate, 23 (Feb)

sleep/waking patterns in, 23 (Feb)

Nephrotic Syndrome

seizures and Friedreich's Ataxia, 397 (Aug) Abs

Nerve

conduction and platelet function in uremia, 322 (Nov) Abs

glossopharyngeal and airway constriction, 232 (Aug) Abs

scar prevention in peripheral, 221 (Aug)

Nerves

injection injuries of, 143 (May)

peripheral, 143 (May)

Neurite

growth and peripheral nerve segments, 322 (Nov) Abs

Neuroblast

encephaloclastic lesions, 191 (Aug) migration, 191 (Aug)

Neuroleptics

extrapyramidal motor disorders associated with, 239 (Aug) Abs

Neurology Training

problem based approach, 327 (Nov) Abs

Neurolysis

ulnar nerve and silastic sheathing, 324 (Nov) Abs

Neurone

activity and anesthetics, 232 (Aug) Abs

Neuropathies

localization of entrapment, 336 (Nov) Abs

Neuropathy

autonomic in streptozotocin diabetic rat, 135 (May)

chain-saw, 322 (Nov) Abs

chronic renal failure, 89 (May)

giant axonal, 177 (Aug)

hereditary demyelinating infantile, 323 (Nov) Abs

hereditary sensory, 73 (Feb)

peripheral in children, 325 (Nov) Abs

visual and oculomotor deficits, 177 (Aug)

Neuropsychiatric Disorders

GABA, 257 (Aug)

Neuropsychopharmacology

Canadian College of, 227 (Aug)

Neurotransmitters

cerebral amino acid, 447 (Nov)

effect of asparagine on, 447 (Nov)

effect of glutamine and insulin on, 447 (Nov)

Noradrenaline

radioenzymatic assay, 230 (Aug) Abs

Noradrenergic Function

depression, 267 (Aug)

Norepinephrine

DHPG formation in CNS, 230 (Aug) Abs

Normocephalus

high pressure, 211 (Aug)

Nortriptyline

neuroendocrine investigations, 228 (Aug) Abs

Oculodermal Melanosis

multiple intracranial tumors, 101 (May)

Oligoclonal Banding

275 (Nov)

Oral Glucose Tolerance

in Friedreich's Ataxia, 397 (Nov), 401 (Nov)

Osteolysis

cerebral and cerebrospinal fluid fistula, 39 (Feb)

Pain

temperature dissociation in hereditary sensory neuropathy, 73 (Feb)

Paraplegia

rhizotomy for spasm in, 330 (Nov) Abs

Para-Tyramine

isolation of in rat brain, 235 (Aug) Abs

Parkinsonism

provoked by alcoholism, 332 (Nov) Abs

Penicillin Spikes and Spindles

324 (Nov) Abs

Periaqueductal Gray Stimulation

anesthetic requirements after stimulation, 334 (Nov) Abs

Peripheral Nerve 
blood nerve barrier after injury, 335 (Nov) Abs internal neurolysis and surgery, 335 (Nov) Abs

Peripheral Neuropathy

chronic renal failure, 89 (May)

Phenylalanine

behavior and biochemical effects, 229 (Aug) Abs

dietary restriction and visual attention span in phenylketonuria, 127 (May)

Phenylethylamine

and urinary excretion metabolites, 231 (Aug) Abs

Phenylketonuria

effect of dietary phenylalanine restriction, 127 (May)

visual attention span and, 127 (May)

Phosphatidylcholine Therapy

in Friedreich's Ataxia, 413 (Nov)

Pineal

tumors and vascular lesions of in children, 332 (Nov) Abs

Pituitary Adenoma

sella abnormalities, 319 (Nov) Abs

Platelets

Huntington's chorea, 281 (Nov)

in Friedreich's Ataxia, 417 (Nov)

Plexopathy

and sensory stimulation, 322 (Nov) Abs

Pneumocephalus

post-operative tension, 328 (Nov) Abs

Polyneuropathy

nerve conduction in chronic relapsing, 322 (Nov) Abs

pregnancy immune globulin and plasmapheresis, 325 (Nov) Abs

Post Mortem

increases in GABA receptor binding, 19 (Feb)

Program

XVth Canadian Congress of Neurological Sciences, 317 (Nov)

Progressive Multisystem Degeneration

with retardation and seizures, 323 (Nov) Abs

Protein

synthesis and polysomes from fibroblasts in Duchenne Muscular Dystrophy, 115 (May) Abs

Protein Kinase Activity

of human erythrocytes in Friedreich's Ataxia, 425 (Nov)

Protein Labelling

dystrophic hamster muscle, 114 (May) Abs

Psychiatric Patients

smooth pursuit tracking in, 233 (Aug) Abs

Psychological Measurements

in relation to cerebral organic changes in Alzheimer's Disease, 45 (Feb)

Putamen

cellular changes, 87 (May)

Huntington's disease, 87 (May)

Pyruvate Dehydrogenase

in platelets from Friedreich's Ataxia, 417 (Nov)

Radiculopathy

sensory stimulation, 322 (Nov) Abs

Reflex

vestibulo-ocular and non-visual control, 327

(Nov) Abs

\section{Reflexes}

crossed adductor and EMG observations, 326

(Nov) Abs

Renal Failure

peripheral neuropathy, 89 (May)

Representation

motor cortex, 79 (May)

Reticular Formation

and trace amine, 228 (Aug) Abs

Rhabdomyosarcoma

neurological manifestations of in children, 319 (Nov) Abs

Ribonucleic Acids

and protein synthesis in embryonic chicken muscle, 125 (May) Abs

Scar

prevention in peripheral nerve surgery, 221 (Aug)

Schizophrenia

chronic and the AMDP rating scale, 239 (Aug) Abs

serum prolactin and growth hormone levels in, 232 (Aug) Abs

Scleroderma

neurological involvement in children, 331 (Nov) Abs

Scoliosis

in Friedreich's Ataxia, 383 (Nov)

Seizures

and intracranial surgery, 285 (Nov)

focal motor, 79 (May)

precipitated by mental arithmetic, 330 (Nov) Abs

Septal Rats

and chlordiazepoxide, 234 (Aug) Abs

Serotonin Receptors

chronic amphetamine on, 239 (Aug) Abs

Sleep/Waking Patterns

in narcolepsy/cataplexy, 23 (Feb)

Spinal

subdural hematoma, 326 (Nov) Abs

Spinal Cord

injury and recovery, 324 (Nov) Abs

Streptozotocin

induced diabetes and neuropathy, 135 (May)

Stroke

myocardial lesions, 321 (Nov) Abs

Subarachnoid Hemorrhage blood-brain barrier dysfunction and, 335 (Nov) Abs

Subdural

spinal empyema, 323 (Nov) Abs

Subdural Empyema

negative C T Scan, 67 (Feb)

Subdural Hematoma growth mechanisms, 334 (Nov) Abs

Subgaleal Mass

from extradural hematoma, 71 (Feb)

Surgery

intracranial and seizures, 285 (Nov)

Synaptosomal Model

and changes in GABA content of nerve endings, 253 ( $\mathrm{Aug}$ )

and research on antipsychotic drugs, 253 (Aug)

Syndrome

Balint's, 157 (May)
Syringomyelia

delayed metrizamide $\mathrm{C} T, 328$ (Nov) Abs

treatment with syringo-subarachnoid shunt, 324 (Nov) Abs

Taurine

in cardiomyopathic hamsters, 435 (Nov)

Temperature

pain disassociation in hereditary sensory neuropathy, 73 (Feb)

3-Acetyl Pyridine Ataxia in Rats

aspartate on, 451 (Nov)

glutamate on, 451 (Nov)

Threshold

motor cortex excitability, 79 (May)

Thrombosis

intracranial venous during pregnancy, 321 (Nov) Abs

Trace Amines

mental disorders, 26I (Aug)

Transient Ischemic Attacks

versus late-life migraine, 9 (Feb)

Tremor

with ataxia and amyotrophy, 345 (Nov)

Trifluoperazine

radioimmunoassay for in human plasma, 237 (Aug) Abs

Tryptamine

and gas chromatograph technique, 237 (Aug) Abs

and nialamide and tranylcypromine, 238 (Aug) Abs

Tryptophan

behavioral and biochemical effects, 229 (Aug) Abs

Tumor

chemotherapy of brainstem, 319 (Nov) Abs multiple intracranial and oculodermal melanosis, 101 (May)

2, 4 Dinitrophenol

dystrophic diaphragm, 114 (May) Abs

2-Phenylethylamine

and nialamide and tranylcypromine, 238 (Aug) Abs

Tyramine

in rat striatum, 236 (Aug) Abs

tritiated from rat striatum, 230 (Aug) Abs

Tyramine Test

depression, 265 (Aug)

Tyrosine

behavioral and biochemical effects, 229 (Aug) Abs

Venesection

cerebral function and chronic lung disease, 293 (Nov)

Verapamil

hamster cardiomyopathy, I/4 (May) Abs

Viloxazine

and response of cortical neurones to acetylcholine, 231 (Aug) Abs

Visual Attention Span

dietary phenylalanine restriction, 127 (May)

in mental retardation with phenylketonuria. 127 (May)

\section{Whipple's Disease}

meningo-ependymitis, 163 (May)

Workshop

Fifth National Scientific on Muscular Dystrophy, 109 (May) 
D'Anville's Doom - A Neurological Vignette From Hlstorlc Halliax - Stephen F. Bedwell

Late-Life Mlgraine Accompaniments as a Cause of Unexplained Transient Ischemlc Attacks - C. Miller Fisher.

Postmortem Increases in Gaba Receptor Binding to Membranes of Cat Central Nervous System - Godfrey Tunnicliff and G. Keith Matheson ...........................

Effects of Nocturnal Gamma-Hydroxybutyrate on Sleep/Waking Patterns in Narcolepsy-Cataplexy - Roger Broughton and Mortimer Mamelak

Hemlspherectomy for the Treatment of Epllepsy and Behavlor Dlsturbance - N.O. Ameli

University of Toronto Neurosurgical Rounds No. 1

Massive Osteolysis in Associatlon With Multiple Cerebrospinal

Fluld Fistulae - Harold J. Hoffman, Derek C. Harwood-Nash, T.P. Morley and N. Barry Rewcastle ......

Relationships Between Psychologlcal Measurements and Cerebral Organlc Changes In Alzhelmer's Disease - H. Merskey, M.J. Ball, W.T. Blume, Allan J. Fox, Hannah Fox, E.L. Hersch, V.A. Kral, R.B. Palmer.

Features of Creutzfeldt-Jakob Dlsease in Brains of Patlents With Familial

Dementia of Alzhelmer Type - M.J. Ball

The Effect of Varlable Duration One Hertz Interference On Kindling - John Gaito

Horner's Syndrome, An Unusual Manifestatlon of Multiple Sclerosis Colin R. Bamford, Michael S. Smith and William S. Sibley

Subdural Empyema With Negatlve C.T. Scan: A Case Report

D.J. Wortzman, W.S. Tucker, D.C. Finlayson, R.S McPhedran and R. Gershater

Chronlc Extradural Hematoma Presentlng With Subgaleal Mass -

Gilbert R.C. Quartey, Youssef H. Gabriel and Stanley Tchang

Hereditary Sensory Neuropathy: A Case With Paln and Temperature Dissoclatlon

Beth O'Brien, R. Jackson, R. Tang-Wai, A.J. Lewis, E.A. Atack

Physlological Basls for Focal, Motor Selzures and the Jacksonlan "March" Phenomenon John T. Murphy, Hon C. Kwan, W.A. Mackay and Yiu Wong .

Peripheral Neuropathles Associated with Chronic Renal Fallure - C.F. Bolton 
Abstracts of the FIfth National Sclentlific Workshop on Hereditary Muscular Dystrophy

Effect of Dletary Phenylalanine Restriction on Visual Attention Span In Mentally Retarded

Subjects with Phenylketonuria - F.D. Griffin, J.T.R. Clarke and D.M. d'Entremont

Dietary Folic Acld and the Activity of Brain Chollnergic and y-Aminobutyric Acid

(GABA) Enzymes - M.I. Botez, Jocelyne Bachevalier and G. Tunnicliff

Autonomlc Neuropathy in the Streptozotocin Diabetlc Rat - George Monckton and Enid Pehowich .....

Clinical and Experimental Aspects of Injectlon Injurles of Peripheral Nerves

Fred Gentili, Alan R. Hudson and Daniel Hunter

Herpes Zoster Mandlbularis - Marcia E. Lewis and Kenneth G. Warren

Ballnt's Syndrome - Chantal O. Hausser, Francoise Robert and Normand Giard

Meningo-Ependymitis in Whipple's Disease - L.R. Lapointe, J. Lamarche, A. Solloum and R. Beaudry .. 163

Notlces and Books

THE CANADIAN JOURNAL OF NEUROLOGICAL SCIENCES

VOL. 7 NO. 3 AUGUST 1980

Sponglform Encephalopathy of Long Duration: A Family Study

G.P.A. Rice, D.W. Paty, M.J. Ball, R. Tatham and A. Kertesz

Glant Axonal Neuropathy: Visual and Oculomotor Deficlts - T.H. Kirkham, D. Guitton and S.G. Coupland

MIgraines Inhabltuelles - Louis E. Roy

Bllateral Encephaloclastic Lesions in a 26 Week Gestatlon Fetus: Effect on Neuroblast Migration Margaret G. Norman

The Relatlonshlp Between Cerebral Blood Flow and the EEG in Normals

Devidas Menon, Zoltan Koles and Allen Dobbs

EMG Blofeedback in Patlents with Motor Disorders: An Ald for Coordinating Activlty in Antagonlstlc Muscle Groups - Alan E. Davis and Robert G. Lee

Motor Radiculopathy - An Unusual Presentation of Multiple Sclerosis

J.H. Noseworthy and L.P.M. Heffernan

University of Toronto Neurosurgical Rounds No. 3

Normal Pressure Hydrocephalus - High Pressure Normocephalus

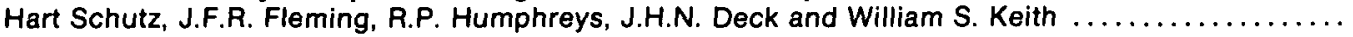

Scar Prevention in Perlpheral Nerve Surgery - Fraser $W$. Saunders $\ldots \ldots \ldots \ldots \ldots \ldots \ldots \ldots \ldots \ldots \ldots \ldots$

Gradient of Interference by Various Frequencles on $60 \mathrm{~Hz}$ Kindling - John Gaito ............. 223

Abstracts of Third Annual Meeting of Canadlan Congress of Neuropsychopharmacology ........... 227 


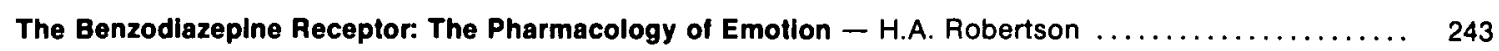

Interactions Between the Benzodiazeplnes, Methylxanthines and Adenosine - J.W. Phillis and P.H. Wu . 247

Organizatlon of GABA-Containing Neurons In Some Extrapyramidal Nuclel - H.C. Fibiger ........ 251

Use of a Synaptosomal Model to Monitor Drug-Induced In Vivo Changes in the $\gamma$-Aminobutyric Acid Content of Nerve Endings and Its Relevance to Research on Antlpsychotic Drugs - J.D. Wood

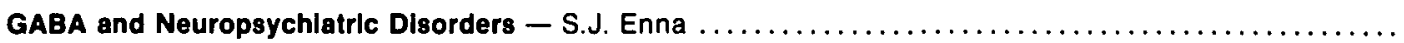

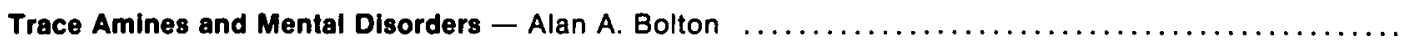

Further Light on the Tyramine Test in Depression

M. Sandler, Susan Bonham Carter, M.A. Reveley, Vivette Glover and Glen Rein $\ldots \ldots \ldots \ldots \ldots \ldots \ldots$

Noradrenerglc Function and Depression, Too Much or Too Little - J.W. Maas and Y. Huang $\ldots \ldots \ldots .267$

Pharmacoklnetic Aspects of Anxlolytic Drug Therapy David J. Greenblatt \& Richard I. Shader ........ 269

Notlces and Books

\section{THE CANADIAN JOURNAL OF NEUROLOGICAL SCIENCES}

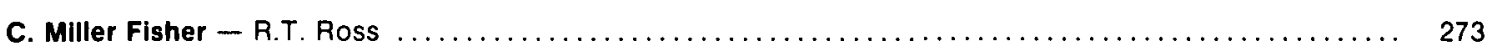

CSF Electrophoresis in One Thousand Patients - G.C. Ebers and D.W. Paty ................ 275

Biochemical Markers for Huntington's Chorea - D.R. McLean and T. Nihei $\ldots \ldots \ldots \ldots \ldots \ldots \ldots \ldots . \ldots 281$

Seizures Following Intracranial Surgery: Incidence in the First Post-Operative Week

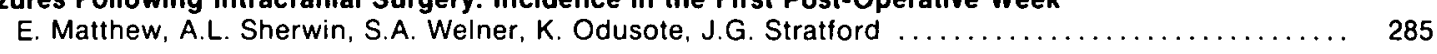

Anaesthetic Barbiturates in Refractory Status Epilepticus

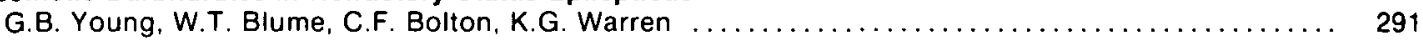

Effects of Venesection on Cerebral Function in Chronic Lung Disease

Robert Bornstein, Devidas Menon, Ernest York, Brian Sproule, Cynthia Zak ............... 293

Auditory Evoked Responses and Computerized Tomography in Central Pontine Myelinolysis

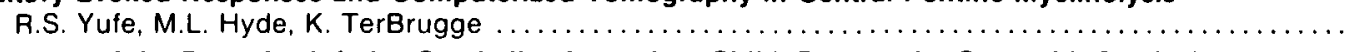

Aneurysm of the Posterior Inferior Cerebellar Artery in a Child: Report of a Case with Survival

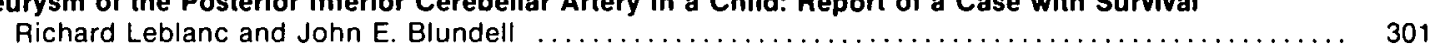

Bilateral Symmetrical Brain Lesions in Tricyclic Antidepressant Overdosage - Laila M. Sabet $\ldots . . .305$

Confusion, Dysphasia, and Asterixis following Metrizamide Myelography - Michael S. Smith and Jose F. Laguna 309

Dysplastic Vertebral Artery with Paradoxical Infarction - Bernadette Curry and Anders A.F. Sima ..... 313

Program and Abstracts of the XV Canadian Congress of Neurological Sciences ............... 317

QUEBEC COOPERATIVE STUDY OF FRIEDREICH'S ATAXIA

PHASE THREE: CLINICAL PATHOPHYSIOLOGY

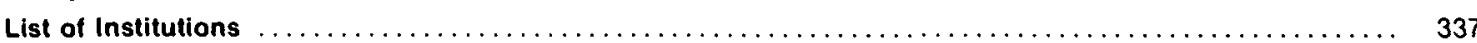

Field Testing of an Ataxia Scoring and Staging System - E. Pourcher and A. Barbeau ........... 339

Study of a Family with Progressive Alaxia, Tremor and Severe Distal Amyotrophy

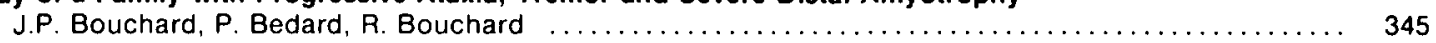

Friedreich's Ataxia in the South of Italy - A Clinical and Biochemical Survey of 23 Patients

G. Campanella, A. Filla, F. Defalco, D. Mansi, A. Durivage, A. Barbeau $\ldots \ldots \ldots \ldots \ldots \ldots \ldots \ldots . \ldots . \ldots 1$

Friedreich's Ataxia in Northern Italy.

I. Clinical, Neurophysiological and in Vivo Biochemical Studies

A. D'Angelo, S. DiDonato, G. Negri, F. Beulche, G. Uziel, R. Boeri $\ldots \ldots \ldots \ldots \ldots \ldots \ldots \ldots \ldots \ldots$

A Preliminary Study of Dynamic Muscle Function in Hereditary Ataxias

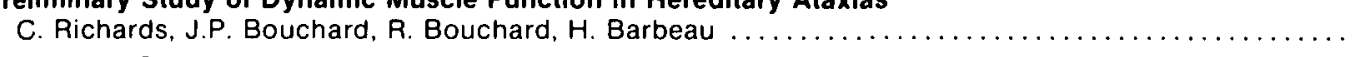

Hypertrophic Cardiomyopathy in Friedreich's Ataxia: Symmetric or Asymmetric?

A. Pasternac, R. Krol, R. Peticlerc, C. Harvey, E. Andermann, A. Barbeau .................. 379 
Pathomechanics and Management of Scoliosis in Friedreich's Ataxia Patients

P. Allard, M. Duhaime, J.V. Raso, P.S. Thiry, G. Drouin, G. Geoffroy

The Cardiomyopathy of Friedreich's Ataxia - Morphological Observations in 3 Cases

J.B. Lamarche, M. Cote, B. Lemieux

Friedreich's Ataxia and Glucose Tolerance: I. The Effect of Ingested Glucose on Serum Glucose and Insulin Values in Homozygotes, Obligate Heterozygotes and Potential Carriers of the Friedreich's Ataxia Gene - G. Tolis, A. Mehta, E. Andermann, C. Harvey, A. Barbeau

Friedreich's Ataxia and Glucose Tolerance: II. The Effect of Ingested Glucose on Serum Growth Hormone in Homozygotes, Obligate Heterozygotes and Potential Carriers of the Friedreich's Alaxia Gene - G. Tolis, A. Mehta, C. Harvey, E. Andermann, F. Andermann, A. Barbeau ..........

Glycosylated Hemoglobins in Friedreich's Ataxia - P. Draper, D. Shapcott, M. Langlois, B. Lemieux .....

Friedreich's Ataxia in Northern Italy. II. Biochemical Studies in Cultured Cells

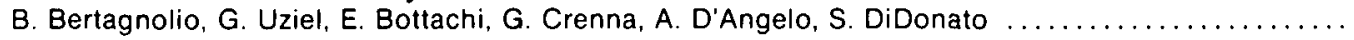

Correlation Between Serum Lipoamide Dehydrogenase Activity and Phosphatidylcholine Therapy in

Friedreich's Ataxia - S.B. Melancon, G. Fontaine, G. Geoffroy, M. Vanasse, L. Dallaire ............

Active Pyruvate Dehydrogenase in Platelets from Friedreich's Ataxia Patients

A. Filla, R.F. Butterworth, A. Barbeau

Leukocyte Glutamate Dehydrogenase Activity in Various Hereditary Ataxias

A. Barbeau, M. Charbonneau, T. Cloutier

Protein Kinase Activity of Human Erythrocyte Membranes in Friedreich's Ataxia - P. Wong and A. Barbeau

Lecithin: Cholesterol Acyltransterase Activity and Fatty Acid Composition of Erythrocyte Phospholiplds in Friedreich's Ataxia - Y.S. Huang, Y.L. Marcel, C. Vezina, A. Barbeau, J. Davignon ...............

Taurine Decreases Lesion Severity in the Heart of Cardiomyopathic Hamsters

J. Azari, P. Brumbaugh, A. Barbeau, R. Huxtable

The Beta-amino Acid Transport System in Friedreich's Ataxia

S.B. Melancon, B. Grignon, E. Ledru, G. Geoffroy, M. Potier, L. Dallaire, M. Vanasse .

Effect of Asparagine, Glutamine and Insulin on Cerebral Amino Acid Neurotransmitters

R.F. Butterworth, F. Landreville, E. Hamel, A. Merkel, F. Giguere, A. Barbeau

Effects of Glutamate and Aspartate on Ataxic Gait Induced by 3-acetyl pyridine in Rats

G. DeMichele, F.B. Jolicoeur, D.B. Rondeau, R.F. Butterworth, A. Barbeau ................ 451

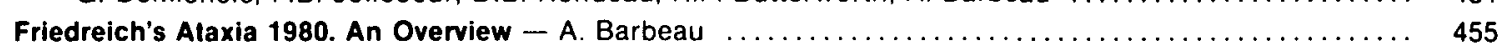

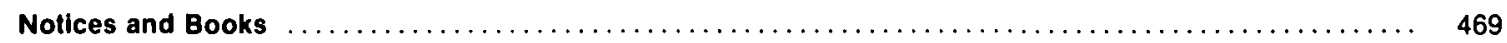

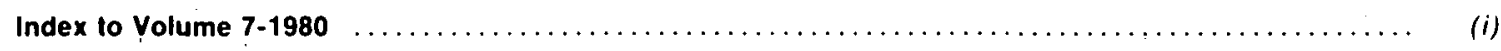

